\title{
LA NUEVA POESÍA BRASILEÑA Y LA REALIDAD SOCIAL
}

\author{
RODOLFO MATA \\ Instituto de Investigaciones Filológicas \\ Universidad Nacional Autónoma de México
}

La reinserción de la realidad social en la producción poética brasileña actual constituye una vertiente que se ha venido fortaleciendo poco a poco. El desgaste del lugar social del poeta, aunado a la crisis del sujeto lírico --heredada de la poética de asepsia sentimental de João Cabral de Melo Neto, llevada al extremo por los poetas concretos--, parece haber desembocado en una pulsión angustiosa por expresar la realidad social, dar testimonio de su trama, promoviendo una conciencia moral lo mismo individual que pública.

En este complejo movimiento entran en juego, a mi modo de ver, tres factores que tienen sus antecedentes históricos: 1) los ecos de la poesía comprometida ideológicamente de los años 60 y 70 ; 2) los peligros de la denuncia panfletaria a los que condujo; y 3) la contención propugnada por la "poesía de objetos", que ha adaptado su "neutralidad" a una mera enunciación cruda de la realidad.

La poesía comprometida de los años 60 y 70 es, desde luego, un producto del clima que antecedió a la dictadura militar iniciada con el golpe de estado de 1964: la Guerra Fría, la ideología de izquierda apoyada por la Unión Soviética, la Revolución Cubana, etc. El deseo de "participar", como lo apunta Charles Perrone, era un imperativo no sólo en el discurso disidente, sino en el oficial: se "participaba" para construir un nuevo Brasil, por ejemplo, el Brasil cuyo emblema era la ciudad planeada de Brasília, bajo el gobierno modernizador de Juscelino Kubitschek. Al analizar un ejemplo emblemático de este tipo de poesía, el caso del colectivo Violão de Rua, que produjo una serie de 3 antologías homónimas de poesía engagée, Perrone apunta un hecho importante y distintivo: existía entonces una firme creencia en el 
papel del arte dentro de lo que se pensaba que era una etapa pre-revolucionaria. Había un horizonte utópico y los intelectuales se vieron en la radical disyuntiva de seguir sirviendo, por omisión, a una minoría, en detrimento de la mayoría oprimida, o "posicionarse" a favor de esta última, para participar en el cambio. Es decir, se trataba de marginarse de la Historia o tomar una actitud y "hacer" Historia. La figura del "hombre-común" y la idea del "arte popular" pasaron a primer plano, junto con la condena del beletrismo y del artista burgués. Los universitarios comprometidos, y con ellos muchos poetas, adoptaron posturas que apuntaban hacia la concepción de que las verdaderas preocupaciones de la poesía eran funcionales y temáticas, más que estéticas: combate al antiimperialismo, lucha por la reforma agraria, apoyo a las agrupaciones campesinas, y a los movimientos obreros, etc. ${ }^{1}$

En esas épocas surgieron los CPC's (Centros Populares de Cultura), el primero en Rio de Janeiro auspiciado por la UNE (União Nacional de Estudantes), con la intención de promover proyectos de arte revolucionario --que incluían literatura, teatro, música y cine-- en una lucha de agitación y propaganda para despertar una conciencia de solidaridad contra la alienación antirrevolucionaria. El CPC de Rio de Janeiro publicó entonces una serie de folletos titulada Cadernos do Povo, entre cuyos títulos se contaban:

Que fazem as ligas camponesas?, Quem é o povo no Brasil?, Quem faz as leis no Brasil?, Por que os ricos não fazem greve?, Quem dará o golpe no Brasil?, etc. Fue en esta colección de panfletos donde aparecieron las tres antologías de Violão de Rua, entre 1962 y $1963 .^{2}$

En el primer volumen figuran escritores como Ferreira Gullar, quien ofrece mediante un poema de cordel titulado "João Boa-Morte, cabra marcado para morrer", la narración de la vida infeliz de un peón de hacienda. ${ }^{3}$ Por haber convocado a sus compañeros a protestar contra la imposición de un precio bajo para la compra de las cosechas, Boa-Morte es expulsado de las tierras que trabajaba y colocado en una lista negra como rebelde y sospechoso de comunismo. Si antes pasaba hambres con su familia por la mala paga, ahora no encuentra trabajo en ningún lugar. Varios compañeros ya habían sido asesinados en esta lucha y ahora un hijo suyo muere de hambre en la dolorosa peregrinación. Finalmente, Boa-Morte encuentra refugio y orientación en una Liga Campesina, que le señala el camino correcto de la Revolución. Este tipo de historias ejemplares fue un recurso común entre los artistas comprometidos, aunque también hubo otras estrategias temáticas para satisfacer el deseo de "participar". Una de ellas fue mostrar "hechos incontrovertibles" que orillaban a "tomar conciencia" de la situación y a adoptar una actitud. Así, en el poema "Quatro mortos por minuto", Ferreira Gullar denuncia una triste realidad latinoamericana propiciada por el capitalismo yanqui: la velocidad que ha adquirido la muerte por hambre, por miseria y enfermedad, entre los brasileños, mientras las arcas de los trusts se abultan a razón de "mil dólares por minuto". La comparación arroja como resultado que se paga ese precio por obtener cuatro muertos por minuto. En las últimas estrofas, el poeta hace un llamado al lector, con una parodia de Benjamin Franklin y el grito de independencia de Fidel Castro: "No tempo que dispendeste / para ler estas estrofes / quatro dos nossos morreram / e o ianqui encheu mais seu cofre // Tempo é dinheiro -- eles dizem. / Tempo é sangue -- nós dizemos. / Fidel mostrou-nos a rota: / Pátria ou morte! Venceremos!". 4

Los dos poemas de Ferreira Gullar siguen patrones métricos regulares, a imitación de la tradición popular. Esta estrategia de identificación ideológica a través de los recursos retóricos 
fue frecuente en la poesía comprometida de los sesentas, pero no fue la única. En el poema "A meta física" del mismo volumen de Violão de Rua, Geir Campos utiliza el verso libre para ofrecer un panorama escandaloso del subdesarrollo y la marginación, en choque frontal con la apatía de las actitudes de alienación filosofante, pero sostenida precisamente en el entendimiento claro de en qué consiste ese pernicioso dilentantismo. Veamos:

\section{A META FÍSICA}

Aos que espiralam sem-razões do ser pergunto:

$$
\begin{aligned}
& \text {--Que vai ser } \\
& \text { das } 130.000 \text { crianças sem escolas } \\
& \text { na principal cidade do país? }
\end{aligned}
$$

Aos que perquirem os fins da existência pergunto:

$$
\begin{aligned}
& \text {--Quanta gente há no país } \\
& \text { sem meios de subsistência? }
\end{aligned}
$$

Aos que pendengam entre o eterno e a hora pergunto:

$$
\text { --E agora? }{ }^{5}
$$

Aunque el lenguaje es sencillo y el mensaje es muy claro --tal como sucede en los poemas de Ferreira Gullar antes comentados--, el público al que va dirigido explícitamente es otro. Mientras los primeros apuntan hacia el campesino y la "gente común", el segundo va dirigido primordialmente a personas instruidas que entienden que hay "problemas filosóficos" y que entre ellos están los de la "la existencia" y "el ser". Además de la diferencia mencionada respecto a los esquemas métricos, hay otras distinciones en el plano formal relativas al tono y la complejidad de los juegos verbales. En "João Boa-Morte, cabra marcado para morrer" y "Quatro mortos por minuto" estos juegos verbales se reducen prácticamente a las rimas propias de la poesía popular. Fuera de eso encontramos sólo unos cuantos elementos, como la parodia de la frase de Franklin ya mencionada. En cambio, "A meta física” incluye, a la par del llamado tácito a la concientización acerca de la realidad del país, otro tipo de juegos verbales, algunos señalados tipográficamente con cursivas, que subrayan un tono irónico. Por ejemplo, el problema metafísico del ser se transforma en la perífrasis verbal "vai ser" que pregunta por el futuro de los niños, y eso da entrada a que las palabras "fins" y "meios" sean leídas en el mismo registro irónico, a la vez que la rima entre "existência" y "subsistência" refuerza esta impresión de lectura. Incluso el título del poema llama al lector a despertar de la "metafísica" para alcanzar una "meta física", es decir, una finalidad palpable. En el último paralelo irónico señalado con cursivas, entre "o eterno e a hora" y "E agora", tal vez se puedan vislumbrar ecos del famoso poema "José" (1942) de Carlos Drummond de Andrade, que repite el estribillo "e agora?". 6

Una última observación en la comparación de estos poemas. Si los de Ferreira Gullar tienen la posibilidad de ser leídos en voz alta ("João Boa-Morte" tiene incuso la marca textual 
que contrasta un escenario, "este palco de rua", donde supuestamente se enuncia el poema, y lo confronta con el "palco do sertão", escenario donde la lucha agraria deberá continuar), "A meta física" es un poema para ser leído en el papel, por la naturaleza de sus juegos verbales que mezclan tipografía.

Después de que el golpe militar de 1964 se consolidó, la represión sistemática del gobierno se inició, los CPC's fueron disueltos y los poetas tuvieron que replegarse. Sin embargo, la poesía de corte social y político tendría continuidad, como lo señala Heloísa Buarque de Hollanda en su histórica antología 26 poetas hoje (1975), aunque una continuidad aligerada de su carácter "misionero y esquemático". Algunos poemas incluídos en ella son buenos ejemplos de este cambio, como es el caso de "Muito obrigado", del libro Passatempo (1974) de Francisco Alvim, en que tiene lugar una entrevista intimidante entre un yo poético y testimonial y un interlocutor cuya identidad ambigua pudiera ser la de un militar:

\section{MUITO OBRIGADO}

Ao entrar na sala

cumprimentei-o com três palavras

boa tarde senhor

Sentei-me defronte dele

(como me pediu que fizesse)

Bonita vista

pena que nunca a aviste

Colhendo meu sangue: a agulha

enfiada na ponta do dedo

vai procurar a veia quase no sovaco

Discutir o assunto

fume do meu cigarro

deixa experimentar o seu

(Quanto ganhará este sujeito?)

Blazer, roseta, o país voltando-lhe

no hábito do anel profissional

Afinal, meu velho, são trinta anos

hoje como ontem a meio-dia

Uma cópia deste documento

que lhe confio em amizade

Sua experiência nos pode ser muito útil

não é incômodo algum

volte quando quiser ${ }^{8}$

En el poema no hay ninguna ideología revolucionaria sino un velado clima de represión, que se manifiesta en forma de angustia, sentimiento producido por la ambivalencia de la información que transmite la trama hecha de fragmentos narrativos, líneas de un diálogo equívoco en que la identidad de los involucrados no es clara, líneas que parecen resultado de 
un monólogo interior, lo mismo que descripciones de una oficina con una "bonita vista" y de un atuendo que consta de un saco, una "roseta" (distintivo que puede ser militar) y un anillo profesional. La situación incluye elementos que enrarecen el ambiente: la copia de un documento, entregada en "confianza", sangre recogida, una aguja en la punta de un dedo, la búsqueda de una vena en un lugar tan inverosímil como un sobaco y la mención de un periodo de treinta años.

El poema "Só dos terratenientes" de Chacal, que también aparece en 26 poetas hoje, igualmente abandona el terreno ideológico-programático. Veamos:

\section{SÓ DOS TERRATENIENTES}

não tenho nenhuma observação

a fazer sobre a vista da varanda.

nenhuma,

a não ser o céu largo e iluminado

dos subúrbios do rio de janeiro.

céu q se alonga ao longo do mundo inteiro.

não é de todo mundo a terra q é redonda. ${ }^{9}$

El título de tonalidades de protesta agraria choca irónicamente con el contenido de un libertarismo existencial, expansivo y juvenil, que ensancha el cielo de Rio de Janeiro hasta abarcar todo el mundo. Sin embargo, el último verso sorpresivamente restringe la expansión pues afirma, de nuevo irónicamente, que la tierra, a pesar de ser redonda, no es de todos: es sólo de los terratenientes. La denuncia existe, de manera a la vez jocosa y amarga, sin programa ni utopía.

Es necesario subrayar que la antología de Buarque de Hollanda retrata un cambio: la entrada plena de la contracultura, la generación del mimeógrafo, la poesía marginal. La solemnidad y la actitud profética de la militancia ya había cedido parcialmente ante la informalidad, el antiestablishment y la liberación de costumbres, ideas y valores que se sostenían en el seno de la represión conservadora de la dictadura. Si el poema de Chacal toma la vía festiva y sarcástica, el de Alvim muestra su preocupación social al exhibir el ambiente de sutil temor, pero sin denuncias proselitistas, actitudes proféticas, manifestaciones de dolida empatía con los marginados, o condenas de los conformistas inconscientes. Este cambio es muy palpable en el poema "Revolução", del mismo libro Passatempo de Alvim:

\section{REVOLUÇÃO}

Antes da revolução eu era professor

Com ela veio a demissão da Universidade

Passei a cobrar posições, de mim e dos outros

(meus pais eram marxistas)

Melhorei nisso -

hoje já não me maltrato

nem a ninguém ${ }^{10}$ 
Es posible pensar, a partir del poema, que la nueva "revolución" es ese abandono del radicalismo para ya no maltratar a nadie.

Mencioné al comienzo de este escrito los peligros de la denuncia panfletaria. ¿Cómo se creó esta imagen de fracaso de la poesía política y/o social más allá del desgaste ético del "maltrato" personal mencionado por Alvim? Surgió de la crítica realizada desde la idea de poesía que imperaba (poesía discursiva, de sujeto lírico y temática intimista, filosófica, mística, sentimental, etc.) pero también del debate con las neovanguardias formalistas y semioticistas, ya presentes o en gestación, como el Concretismo (1956), la Poesia Semiótica (1964) y el Poema/Processo (1967). Por ello, Heloísa Buarque de Hollanda sugiere que la confluencia de posturas politizadas --como la del CPC-- con posturas formalistas --como las de las vanguardias experimentalistas--, así como el carácter aparentemente irreductible del antagonismo entre ellas, abrieron la posibilidad de que la producción cultural brasileña profundizara en sus problemas. Ambas tendencias perseguían aspectos revolucionarios de la palabra poética, pero desde diferentes puntos de vista. Aunque frecuentemente cruzaron acusaciones, pretendían participar: unos, bajo la utopía revolucionaria comunista, con miras a transformar la estructura social --dando énfasis a la figura del campesino, base de una economía primaria y emblema de la marginación--; otros, bajo la utopía desarrollista, que buscaba modernizar al país apoyando la industrialización, exaltando los poderes de la tecnología, incorporando las novedades del exterior, y considerando a la figura del obrero como un elemento central. ${ }^{11}$

De esta manera, los principales posturas que la crítica imperante consolidó sobre la poesía política y/o social se agruparon en los siguientes argumentos: 1) la reducción de la ambigüedad, de la plurisignificación connatural al discurso poético para privilegiar la comunicación clara y "útil", contradecía los principios fundamentales de la poesía; 2) la actitud antielitista, para ampliar el público y alcanzar a las masas, provocaba un descenso en el nivel del discurso, un empobrecimiento en términos estéticos; 3) se generaba frecuentemente una postura paternalista, pedagógica y maniquea, apoyada en estereotipos (el campesino, el trabajador, el revolucionario, el burgués, etc.) que propiciaba el surgimiento de fetiches de batalla.

En el campo de los debates, menciono dos casos, entre muchos. El primero es el rompimiento de Ferreira Gullar con el Concretismo, a raíz de la publicación del ensayomanfiesto "Da fenomenologia da composição à matemática da composição" de Haroldo de Campos (1957), y la consecuente fundación del Neoconcretismo (1959). En el manifiesto inaugural de este último, firmado por Ferreira Gullar y otros artistas, se condena la "peligrosa exacerbación racionalista" del concretismo, que privilegiaba la teoría por encima de la obra, mecanizándola, restándole libertad. Esta distancia, originalmente de orden estético-conceptual, se recrudeció al sumársele la dimensión ideológica, cuando Ferreira Gullar subrayó su militancia de izquierda uniéndose al CPC de Rio de Janeiro, en 1962, y adoptó sus lineamientos estéticos. Sin embargo, las presiones del compromiso político-social ya habían entrado en vigor un poco antes, pues los concretistas citaban a Marx en sus escritos desde 1960 y, en 1961, ya habían adosado a su manifiesto fundacional "plano-piloto para poesia concreta" (1958, Noigandres 4), la leyenda: "post-scriptum 1961: "não há arte revolucionária sem forma revolucionária' (maiakóvsky)”. Ese mismo año, en un congreso en Assis, Décio Pignatari 
anunció el "salto conteudístico-semântico-participante" y, al año siguiente, Haroldo de Campos le dio vestidura teórica en "A poesia concreta e a realidade nacional". ${ }^{12}$ Por otra parte, Mario Chamie lanzó el manifiesto "Poema-Práxis" (1962), en el que proponía una serie de técnicas para subsanar la brecha que se había abierto entre la poesía, como arte del lenguaje, y la realidad extralingüística. Contaba con no haber incurrido en los excesos formalistas, racionalistas y, en consecuencia, "alienados", de los concretos, pero su propuesta exigía un discernimiento de recursos semióticos fuera del alcance de un lector no informado. ${ }^{13}$ Ambas propuestas subrayaban la posibilidad de fusionar la estética del CPC y la de las vanguardias formalistas. Dos ejemplos que tomo como emblemáticos de estas fusiones de "formalismo comprometido" son el poema visual-concretista "Beba Coca Cola" (1957) de Décio Pignatari y el poema de Mario Chamie "Compra e venda II", publicado en el libro Lavra-Lavra (1962). Este último es usado por el autor como ejemplo de la aplicación de los principios descritos en el manifiesto "Poema-Práxis", texto incluido como posfacio del mismo libro.

Varios fracasos fueron corroborados con el paso del tiempo: 1) A pesar de que se pretendía romper con las posturas elitistas, se presentó una gran resistencia de parte de los poetas a claudicar de su lugar especial, sin duda un resabio romántico en sintonía con el espíritu revolucionario. Muestra de lo anterior es que los trabajos colectivos elaborados por los poetas concretos pronto regresaron a tener autoría definida. 2) La clase media ilustrada generalmente falló en la promoción de una sensibilidad identificada con las clases trabajadoras, pues los consumidores de este tipo de poesía pertenecían más al propio gremio de los poetas que al público general al que supuestamente estaba dirigida. Esto fue mucho más palpable en el caso del formalismo comprometido, a pesar de los esfuerzos didácticos realizados para educar al lector en lugar de disminuir el nivel de complejidad. 3) El valor adoctrinador del arte fue seriamente cuestionado, no porque careciera de impacto sino porque su efectividad no resultó la esperada. ${ }^{14}$ Quizá por esa razón la salida de la crisis planteada por las exigencias de los compromisos político-sociales fue en gran parte la espontaneidad, el desparpajo y el cinismo de la poesía marginal. A pesar de que los rasgos de la poesía políticosocial relacionados con los puntos anteriores desaparecieron, hubo otros que se conservaron, como la emotividad impostada que en ocasiones lograba crear un clima de pathos, de drama. Más adelante comentaré otros rasgos con la revisión de algunos ejemplos de poesía contemporánea.

Desde luego, en la tradición literaria brasileña existe poesía sintonizada con el tema político-social anterior a la de los volúmenes de Violão de Rua. Ejemplos muy claros se pueden encontrar en libros de dos de sus más grandes poetas: A rosa do povo (1945) de Carlos Drummond de Andrade y $O$ cão sem plumas (1950), O Rio (1954) y Morte e vida severina (1956), de João Cabral de Melo Neto. En el caso de Drummond, la preocupación políticosocial, marcada por el clima amenazante del nazifascismo de la Segunda Guerra Mundial, no pretende penetrar en las masas con el objetivo de concientizarlas, sino que mantiene hacia ellas una distancia aristocrática lo mismo que una actitud de profunda inconformidad que busca conmover a las élites intelectuales. ${ }^{15} \mathrm{El}$ yo del poeta y su aproximación personal y sentimental a sus personajes y al lector están muy presentes y continúan el tono íntimo y confesional de José (1942), junto con la absorción y proyección de emociones palpables en Sentimento do mundo (1940). El caso de Cabral es muy diferente, pues sus libros inmediatamente anteriores, 
O engenheiro (1945) y Psicologia da composição (1947), ya plantean un rechazo de la inspiración y de la poesía lírica y confesional, y hacen énfasis en la idea del poema como artefacto, de su apreciación a través de la razón y el intelecto y de su composición como fruto de un arduo trabajo. Esta postura, enarbolada casi a nivel de axioma por el Concretismo, dio lugar a lo que he llamado, al principio de este escrito, "asepsia sentimental". Sin embargo, resulta difícil pensar que haya una ausencia total de sentimientos o emociones en las obras mencionadas del autor pernambucano que aborden temas político-sociales. Lo que está presente, sin duda, es una contención. Los llamados a la conciencia del lector y las actitudes de denuncia se limitan --en lo posible-- a ser comunicados a través de la presentación de realidades, imágenes y escenas seleccionadas para tales efectos. Hay una proximidad con la militancia de izquierda, que señala la miseria y sufrimiento de los desposeídos. Se denuncia la desigual distribución de la riqueza y sus consecuencias inmediatas, lo cual remite a una crítica focalizada en el sistema económico. Esta "poesía de objetos" -como también la he llamadocontinúa siendo usada, aunque hoy ha cambiado y remite no solamente a la dimensión económica, sino a diversos aspectos de la sociedad contemporánea.

Para revisar una muestra de la situación actual de la poesía de corte social y político he elegido algunos poemas de cuatro autores: Claudia Roquette-Pinto (1963), Fábio Weintraub (1967), Régis Bonvicino (1955) y Fabricio Carpinejar (1972). El primero que he elegido analizar es el poema "Sítio", de Claudia Roquette-Pinto, publicado suelto en 2001 en la revista Inimigo Rumor e incluido más tarde en el libro Margem de manobra (2005), donde ningún otro poema ofrece una temática parecida:

\section{SÍTIO}

O morro está pegando fogo.

$\mathrm{O}$ ar incômodo, grosso,

faz do menor movimento um esforço, como andar sob outra atmosfera, entre panos úmidos, mudos, num caldo sujo de claras em neve.

Os carros, no viaduto, engatam sua centopéia:

olhos acesos, suor de diesel, ruído motor, desespero surdo.

O sol devia estar se pondo, agora

-- mas como confirmar sua trajetória debaixo dessa cúpula de pó, este céu invertido?

Olhar o mar não traz nenhum consolo (se ele é um cachorro imenso, trêmulo, vomitando uma espuma de bile, e vem acabar de morrer na nossa porta). Uma penugem antagonista 
deitou nas folhas dos crisântemos

e vai escurecendo, dia-a-dia,

os olhos das margaridas,

o coração das rosas.

De madrugada,

muda na caixa refrigerada,

a carga de agulhas cai queimando

tímpano, pálpebras:

O menino brincando na varanda.

Dizem que ele não percebeu.

De que outro modo poderia ainda

ter virado o rosto: "Pai!

Acho que um bicho me mordeu!" assim

que a bala varou sua cabeça? ${ }^{16}$

El poema está construido con un montaje de escenas "narrativas", que crean un clima tenso con un desenlace sorprendente. El sujeto que narra no es neutral: el morro está "pegando fogo", es decir, algo alarmante (en el sentido figurativo de la expresión) tal vez un incendio (en el sentido literal de la expresión) sucede en él, lo cual es tan ambiguo como el "caldo sujo de claras em neve". Hay una sensación de asfixia por calor, la pesadumbre de un embotellamiento, un mar que "vomita bile" y no consuela, un jardín con flores siendo destruidas poco a poco por una "penugem antagonista". El mismo sujeto, en la última escena, se define como femenino, pues se trata de una ella que se encuentra "muda na caixa refrigerada". ¿O será la "carga de agulhas" la que se encuentra "muda na caixa" y el sujeto sigue sin tener género? ¿La "caixa refrigerada" es un refrigerador donde está una "carga de agulhas" o un cuarto con aire acondicionado? No lo sabemos ni lo sabremos. La ambigüedad y el montaje de escenas es parte integral del poema y recuerda un poco la estructura de "Muito obrigado", de Francisco Alvim, con la diferencia de que en "Sítio" puede haber una multiplicidad de temporalidades y no solamente de espacios pues, a la escena en exteriores -en la que se contempla el morro y los carros en el viaducto-, no forzosamente sigue en secuencia la que sucede en la madrugada, ni tampoco sabemos qué estatuto temporal guarda la de la noticia del niño baleado, que incluso puede corresponder no a la primera impresión en la psique del sujeto sino a la memoria de dicha impresión que se niega a desaparecer y regresa por la madrugada. ${ }^{17}$

Si tomamos la opción de que el sujeto sea femenino - un reflejo de la poeta, así como la ciudad en que sucede bien pudiera ser Rio de Janeiro, donde ella reside, a pesar de que no hay ninguna alusión específica -, podemos continuar y suponer que dicho sujeto se encuentra en una situación enigmática, recibiendo una "carga de agujas" que cae quemando "tímpano e pálpebras". Parece entonces sugerirse metafóricamente que el sujeto se entera de una noticia la lee, la escucha o la contempla en los medios electrónicos y por eso está en cursivas - en que un niño cae herido por una bala perdida y le dice a su padre: "Pai! Acho que um bicho me mordeu!". La sorpresa es inmediata y la fatalidad y la injusticia aparecen como consecuencias incontornables de una situación social: la muerte de un inocente que exhibe - involuntaria- 
mente, por supuesto - su inocencia. El contraste surge en preguntas acerca de la distancia entre el sujeto narrador y la víctima en la noticia. El poema es, desde luego, la denuncia de la violencia. No podemos afirmar que el niño sea un niño pobre de alguna favela - aunque parece sugerirse eso en el íncipit "o morro está pegando fogo" - sino por exclusión: de ser un niño rico, su posición económica estaría muy probablemente consignada y enfatizada en la noticia. Sospechamos, por el montaje, que la narradora tiene carro, jardín y aire acondicionado en casa, pero tampoco podemos afirmarlo. Mucho menos podemos asegurar que sea la autora y que se trate de un episodio autobiográfico o pseudoautobiográfico. Una lectura seca, sin superinterpretaciones, sólo permite afirmar que lo que existe es el clima de temor, la culpa del sobreviviente y el contraste entre quienes están expuestos a ser alcanzados por balas perdidas y aquellos que se encuentran alejados de estos peligros. Y esto se debe también a que todo el discurso previo a la noticia periodística es impersonal y sólo la noticia da cuerpo a las personas del padre y el hijo. La presencia de quien narra sólo es marcada a través de partes de su cuerpo, sensaciones y acciones: el aire incómodo y grueso, la dificultad de movimiento, la ausencia de consuelo, la posible mudez, el tímpano y los párpados.

La observación acerca del contraste entre los "protegidos" y los que viven en la miseria, y sobre la manifestación del sujeto poético de manera impersonal a través de sus huellas corporales en el texto, aparecen en el ensayo "Situação de sítio", de Iumna Maria Simon, que es el análisis más detallado hasta la fecha del poema de Claudia Roquette-Pinto. Me detengo en él porque dibuja un contexto interesante que ayuda a ubicar su aparición, pues señala una vertiginosa transformación de la sociedad brasileña, la cual transita del fin de las políticas de desarrollo al estancamiento económico y aumento de la concentración de la riqueza, y del cosmopolitismo financiero a la desfachatez ideológica de los neoconservadores que "anduvieron con la rienda suelta". En ese panorama, todo se podía esperar -dice Iumna- menos un nuevo ciclo de "retradicionalização da poesia", concepto que significa:

\begin{abstract}
incorporar as tradições modernas, traduzir o teor originariamente crítico delas em formas convencionais e auto-referidas, mediante o trabalho de linguagem e sob o amparo do "rigor de construção", paradoxalmente assumidos como princípios capazes de preservar a autonomia poética e o ofício do verso. Como se vê, fundem-se aí vários horizontes da experiência moderna: a abertura historicista trazida pela existência de um museu da poesia moderna, a consciência formal do poema como artefato lingüístico, o teor construtivo das vanguardas dos anos 1950, a antiga autonomia esteticista e até, quem diria, o gosto provinciano pelo artesanato do verso. De imediato, esse movimento sem programa parecia reagir à desqualificação formal e à baixa mímese a que os poetas marginais haviam submetido a poesia brasileira nos anos 1970, embora tendesse a escapar ao compromisso dos confrontos. Sob a fiança de linhagens prestigiosas da tradição moderna e já sem propósito radical, a invenção poética se desloca da experimentação dos procedimentos (como no tempo da vanguarda) para a conceitualização dos conteúdos, tratados frivolamente como matéria de variações. $\mathrm{O}$ que mudou nesse quadro foi o peso e o sentido da tradição, que não parece incompleta, nem é considerada obstáculo, sequer precisa ser superada ou transformada -- agora todas as tradições estão franqueadas, conquanto o poema desarme a inquietação autoproblematizadora, caracteristicamente moderna, à procura de dicções elevadas e pluralistas que desrealizem sua matéria ao mesmo tempo que a ornamentem. $^{18}$
\end{abstract}

Iumna subraya el desgaste crítico de las diferentes líneas de poesía, su convencionalismo, autorreferencia, rigor constructivo, pero sobre todo, me parece, su autonomía, su desvinculación. De ahí viene la sorpresa ante la retradicionalización, que se repite en la pregunta final del ensayo: ¿Por qué la relación con la tan insatisfactoria realidad actual tardó 
tanto en llegar a la poesía en un país en que la violencia es constitutiva de la propia sociabilidad? En apoyo de su lectura, la autora cita al poeta y crítico Ronald Polito para confirmar que la simple constatación de que en la poesía brasileña "todo es campo de experimentación" de géneros y soportes mezclados, que no rechaza nada, que exige "jugadores cada vez más entrenados" y que se da en una convivencia civil momentánea y sorprendente se ha convertido poco a poco en una justificación que parece un destino. Para Iumna, la poesía brasileña "deixou de ser companheira de viagem do presente, deu as costas aos acontecimentos". 19 Los rasgos que identifica en esa producción que "retradicionaliza frívolamente", que es más que un "regreso antivanguardista a lo literario" y que "acomoda la crisis de representación en moldes aliteratados y poetizantes" son: 1) La recombinación desencantada de erudición y el juego de referencias literarias y artísticas en el espíritu de intertextualidad posmoderna. 2) La escritura abstracta y desencarnada que se poetiza para disfrazar la rarefacción referencial y la indeterminación discursiva aunque subsistan "manchas" de divagación lírica, confesionalismo y alguna reflexión existencial. 3) El agotamiento de la vanguardia y su caída en la rutina que transformaron a la experimentación en ideal de "alta cultura" y refinamiento poético, ideal que se ofrece como respuesta a la "tradición literaria mundial". Todos esos elementos - observa Iumna - convivieron contradictoriamente en la poesía concreta y por eso ésta pudo atravesar las décadas de los años ochenta y noventa del siglo XX.

Sin embargo, a partir de finales de la década de 1990, la mencionada retradicionalización posmoderna perdió fuerza. Iumna da una serie de indicios de este debilitamiento con varios ejemplos en los que el cambio se puede percibir: 1) La sintaxis deja de ser un medio para oscurecer el asunto del poema, cuya disolución se convertía en el espectáculo del desmontaje de sus imágenes, como sucede recurrentemente en la obra de Carlito Azevedo, para ceder espacio a una poesía de horizonte oprimido y desanimado "de rotina de ninharias", como se lee en los libros Planos de fuga e outros poemas (2005) de Tarso de Melo y Terminal (2006) de Ronald Polito. 2) Se descubre el tono menor asociado a contextualizaciones más densas y personales que se concilia con cierto experimentalismo gráfico y de arreglo en bloques verbales, como en los libros de Ricardo Domeneck, Carta aos anfibios (2005) y A cadela sem Logos (2007). 3) Resurge el interés por el poema en prosa con ciertos impulsos de narratividad, como los que recorren, si bien con alguna rarefacción, el mencionado Planos de fuga e outros poemas de Tarso de Melo, o Louco no oco sem beiras (2001) de Frederico Barbosa, que es descrito como una composición de poemas breves que se reestructuran en el cuerpo narrativo de un libro. 4) Sorprende la aparición, en autores ligados a la poesía concreta, o en crisis con ella, de una poesía de reclamación. Los casos citados son Contracorrente (2000) de Frederico Barbosa, en el que Iumna ve indignación y desesperación existencial, y Página órfã (2007) de Régis Bonvicino, que le parece una crítica feroz que llevó a varios reseñistas a calificarla (equivocadamente, queda sólo sugerido) como "poesía política". Iumna concluye esta revisión anunciando que la pérdida de fuerza de la retradicionalización se da a favor de una mayor relevancia del asunto, que exige precisión en su tratamiento, lo que puede tener como consecuencia --si no resulta exagerada la expresión, dice ella-- un "retorno a lo real". Este retorno se puede percibir, señala Iumna, en Novo endereço (2002) de Fabio Weintraub, que se detiene en situaciones de "sufrimiento de la intersubjetividad" en medio de 
destrozos de variada índole que muestran tanto deterioro material como corporal. Para Iumna, la evidencia de este "regreso a lo real" es "a volta da referencialidade concreta, do país real, dos problemas sociais, da decadência urbana, por vezes mesclados ao padrão impositivo da intertextualidade". ${ }^{20}$ Otro ejemplo que Iumna ofrece es Cais (2002), de Alberto Martins, en que la descripción de la ciudad portuaria de Santos se entreteje con la historia y la mitología personal del poeta, los recuerdos de su padre, citas y referencias de viajeros como Richard Burton y Rudyard Kipling, y cronistas como Frei Gaspar da Madre de Deus y José de Anchieta, todo en un tono disfórico que contrasta con el clima de histórica celebración del descubrimiento del Nuevo Mundo y sus promesas de progreso.

Me parece que Iumna ofrece una atinada perspectiva que sirve para describir y articular algunos rasgos muy importantes de esta producción, en términos generales. Sin embargo, habría que matizar los lugares que asigna a los poetas que selecciona como ejemplos, porque cada uno de ellos merecería análisis pormenorizados. Por ejemplo, Iumna habla de la obra de Carlito Azevedo como portadora de un rasgo recurrente - el desmonte de sus imágenes como espectáculo -, apreciación problemática porque la hace parecer uniforme. Si bien hasta la fecha del ensayo de Iumna, 2008, la obra de Carlito estuvo detenida en la autoantología Sublunar (1991-2001) (2001), que recogía poemas de sus cuatro libros anteriores, hay en ella variedad y transformación. ${ }^{21}$ Flora Sussekind, en su ensayo "Desterritorialização e forma literária. Literatura brasileira contemporânea e experiência urbana", señala la irrupción de la realidad urbana en poemas del libro Sob a noite física, a través de la imagen de la basura dispersa en Rio de Janeiro, que acaba transformándose en elemento constitutivo del yo lírico. ${ }^{22}$ ¿Habría en esto un "retorno a lo real" aunque fuera de una manera inconsciente? ¿Se trata del regreso de aquello que había sido negado? ¿Se encuentra este regreso integrado con el espectáculo del desmonte de sus imágenes? Algo similar sucede en el caso de Planos de fuga e outros poemas de Tarso de Melo, pues el libro no puede ser calificado en su integridad como "rotina de ninharias" en un horizonte oprimido y desanimado. Fabio Weintraub, en su tesis doctoral "O tiro, o freio, o mendigo e o outdoor: representações do espaço urbano na poesia brasileira pós1990" (2013), revisa poemas de este libro, en los que identifica la vivencia de problemas como el deterioro del transporte urbano, y de libros anteriores - Lugar algum (2005) y Exames de rotina (2008) -, en los que analiza la representación de los mendigos y habitantes de la calle. ${ }^{23}$ Más adelante regresaré sobre la propuesta de Iumna pero antes es necesario volver a los ejemplos que elegí como muestras de poesía actual de corte social y político.

El segundo ejemplo que deseo comentar es el poema "Barrabás" del libro Novo endereço (2002) de Fabio Weintraub (1967). Es importante subrayar que es justo en este libro en el que Iumna identifica el "retorno de lo real". Veámoslo:

\section{BARRABÁS}

Vocês não podem velar

o corpo do meu marido

ao lado desse aí

que a polícia acertou 


\author{
Vocês me desculpem \\ imagino o sofrimento \\ perder um filho assim moço \\ Meu Cícero \\ morreu trabalhando \\ Um tiro pelas costas \\ às duas da manhã \\ Ao lado do desse aí \\ o corpo dele não vai gelar \\ Não adianta insistir \\ ao lado de bandido \\ meu marido não fica ${ }^{24}$
}

El estilo del poema es directo, económico. Una mujer monologa reclamándole a los encargados de una funeraria el que su marido, asesinado por la espalda, sea velado junto a un criminal muerto por la policía. La indignación, ante la posibilidad de que la honestidad del marido se viera cuestionada por la contigüidad de su cadáver con el de un bandido condenado por la sociedad, pone en evidencia los valores que están en juego. El poema presenta la tragedia de la violencia urbana con la muerte que iguala a los hombres, sean víctimas o verdugos. Como telón de fondo aparece el ejemplo cristiano, introducido por el título del poema, que subraya la fragilidad de la justicia humana: Barrabás fue indultado por Pilatos con la aclamación popular mientras Jesús sufrió la condena que lo llevó a la cruz. Lo interesante aquí es que la interioridad de la viuda es abordada por el poeta mediante una escenificación en que las palabras están muy bien seleccionadas, en cuanto al registro del habla popular y la conformación de un cambio de interlocutores. El primer "vocês" se refiere a los encargados del velatorio mientras el segundo corresponde a los deudos del bandido, a quienes la mujer expresa respeto y comprensión por el dolor de haber perdido un hijo joven. Después de pedir una disculpa protocolar y a la vez sincera - dada la magnitud de los acontecimientos -, la viuda expone sus razones y se muestra inflexible en la salvaguarda del honor de su marido.

Este mismo procedimiento de construcción de personajes, que trata de reproducir el punto de vista propio de cada uno, y que a veces incluye diálogos en estilo directo - como en "Barrabás" - o indirecto, además de descripciones, está presente en poemas del mismo libro, como "Ilha" y "Mãe", que abordan respectivamente los problemas de la drogadicción y la demencia senil; "Pai", que trata del desempleo, y "Cinderela" que ofrece una instantánea de la vejez. Cabe agregar que Fabio Weintraub continúa esta línea temática en su siguiente poemario, Baque (2007), con estrategias retóricas muy parecidas, aunque no dejen de aparecer otras, como en el poema "Love me tender", construido como un montaje de frases de "cultura inútil" como "Escovas de dente azuis / são mais usadas que as vermelhas" o, en sintonía con el título del poema, "7\% dos americanos acreditam / que Elvis Presley está vivo". Esta estrategia retórica se aproxima a las que utiliza Bonvicino, como veremos más adelante.

Como ya mencioné, el autor ha analizado detalladamente algunos aspectos fundamentales de la relación poesía-ciudad en la tesis doctoral " $\mathrm{O}$ tiro, o freio, o mendigo e o 
outdoor: representações do espaço urbano na poesia brasileira pós-1990". En ella, considera temas como la crisis habitacional, el incremento de la violencia, el colapso del transporte y la museificación urbana (instalación de áreas protegidas de patrimonio arquitectónico que se transforman en escenarios), en la producción poética posterior a 1990; traza vínculos con los legados modernista, concretista y de la poesía marginal; e incorpora enfoques provenientes de otras disciplinas, como la arquitectura y la antropología urbanas. Sin duda, toda la experiencia que acarrea esta investigación le ha facilitado a Weintraub - quien originalmente se formó en psicología - la creación de los personajes de sus poemas y la proyección de lo que Iumna califica como "sufrimiento de la intersubjetividad", en los escenarios de deterioro urbano, social y personal.

El tercer ejemplo que he seleccionado es el poema "Indisciplina", del libro Página órfã (2007) de Régis Bonvicino (1955). Es una buena muestra de la búsqueda de la enunciación "neutral" de la realidad urbana globalizada que ha perdido un sistema de valores coherente. Cito los fragmentos necesarios a mi comentario:

\section{INDISCIPLINA}

Casaco vinho, opaco

calça bege de brim desbotado

chinelos ainda

não totalmente gastos

com a mão no queixo

sentado, com um olhar de Nacho

sem relógio, num marasmo

à noite, usa um capuz preto

blusa vermelha, saia

azul estampada, cochilando

ao sol do fim da tarde de

verão numa pose Emina

caída bermuda manchada

olhando a vista do viaduto

camiseta verde regata

calça bege, como anônimo

no meio do tumulto dos carros e ônibus

de saia larga, blusa cavada

fumando à la Eloise

ostensivamente 
camiseta bordô, calça preta de nylon com fio branco nas laterais sapatos bege, como um Noah cruzando a passarela da avenida

vazia, de peito aberto camiseta camuflada calça branca, cinto Rucci, clássico exibindo-se

estilo Nu.Luxe

no banco de trás da estátua blusa preta estrategicamente rasgada

(...)

como uma Inguna malptrapilha, num estilo apátrida sentada na mureta da praça

cabeça baixa

batendo nos joelhos, gravata invisível Hugo Boss camisa branca, calça preta

(...)

a outra, à la Marika, vestido vermelho, descalça, no calor cara féia é fome mesmo camisa azul bêbado

(...)

japonisme, tipo trapista um Buda fedido feche a bolsa acabe com o jogo 


\author{
silhueta resgatada \\ blusa Fendi, calça Armani \\ sapatos Helmut Lang \\ a vítima o reconheceu na rua \\ e chamou a polícia \\ jeans cinza, tênis amarelo \\ desfilando \\ na calçada, lépido \\ $[\ldots]$ \\ botas furadas, grafite \\ à la Yves Saint Laurent \\ sob o sol de cada dia \\ muito glitz, muito glam ${ }^{25}$
}

El poema inicia con la enumeración descriptiva del atuendo de un personaje. El fraseo económico usa el lenguaje típico de las pasarelas de los desfiles de moda. El brim deslavado hace juego con las sandalias desgastadas, y la postura sedente con la mano en la quijada, sin reloj, y una mirada de Nacho -posiblemente Nacho Figueras, un cotizado modelo argentinodesembocan en una apatía que puede conservar el tono blasé. Sin embargo, a partir de la mención de que por las noches usa una capucha negra, la apreciación del lector comienza a dar un giro y a infundirle otro sentido a los pantalones deslavados y las sandalias gastadas. Las descripciones de las siguientes "figuras" se dan en los mismos moldes. La mujer que dormita al final de la tarde de verano es vista posando como Emina Jahovic, cantante y modelo serbia, mientras otro personaje aparece "como un anónimo", con el sentido ambiguo que esta designación puede tener en la oscilación entre el mundo de la moda y la vida de los habitantes de la calle. Este vaivén se resuelve entre la cuarta y la quinta estrofa, en las que se torna evidente que se trata de un grupo de mendigos en el vano bajo un viaducto. Sin embargo, el recurso del contraste se va a prolongar por dieciocho estrofas más, en las que se mencionan otros modelos (Eloise, Noah, Ambrose, Inguna, etc.), marcas (Rucci, Nu.Luxe, Hugo Boss, Zoomp, Kenzo, etc.) y poses, todos articulados siguiendo diversos matices. Por ejemplo, una mujer se "exhibe" al estilo de la marca de lingerie Nu.Luxe, cuando en realidad viste harapos; otra aparece como una Inguna --Inguna Butane, modelo letoniana-- pero ahora ya es designada directamente como una "Inguna andrajosa"; y un hombre cabizbajo luce una "corbata invisible Hugo Boss". Entramados en estos versos descriptivos, el poeta inserta otros que poco a poco, a manera de flashazos, van develando el hambre ("cara feia é fome mesmo") y la marginalidad ("feche a bolsa / acabe com o jogo", "a vítima o reconheceu na rua / e chamou a polícia"). El choque entre lujo y miseria surte el efecto de conmocionar al lector, pero la voz enunciadora se mantiene distante, casi como contemplando maniquíes en un aparador. Es la voz de un espectador que articula con tono irónico los hechos expuestos. La "asepsia sentimental" y la contención de Cabral se mantienen. No hay interacción entre los personajes, pues sus gestos se 
reducen a ser interpretados en la línea del espectáculo de la moda. El cierre del poema es congruente y su ironía --el uso festivo de palabras del mundo de la moda, glitz (lujo ostentoso) y glam (apócope de glamour)-- parece denunciar la indiferencia de los responsables y de los omisos. El título apunta también al contraste: la realidad es indisciplinada y resiste la uniformización de la moda; o, desde otro punto de vista, alude a los juegos de la industria de la moda con las ideas de "rebeldía" y "originalidad".

En el artículo citado, Iumna identifica en Página orfã la misma materia del poema "Sítio". Sin embargo, subraya que la "objetividad ostensiva" produce un "pintoresquismo negativo" tan espectacular como su "violencia antidiscursiva". Aunque el poeta embandera una indignación explosiva y parece anunciar una enérgica respuesta política, es reduccionista pues no alcanza a articular las imágenes del horror económico sino sólo a yuxtaponerlas. "Nessa militância imaginária, entre indignação e fúria -dice Iumna-, Bonvicino dispensa qualquer simpatia social, confiando apenas na heroicização positiva da sua negatividade". Espectaculariza la catástrofe y reserva al poeta un lugar privilegiado, precisamente el de observador con entereza moral que se adjudica el derecho a reprender. Para reforzar su comentario, Iumna cita la reseña que Weintraub hizo del libro: "Sobretudo no que tange à venalidade, o tom de reprimenda é ainda reforçado pela marca de distinção que o eu lírico se atribui, figurando-se como "mau negociante de inutilidades", fabricante de algo que não se vende, portador da redentora "praga das palavras" ([poema] "Prosa")". ${ }^{26}$ Asimismo, "nos poemas habitados por mendigos e toda sorte de refugo humano, não há propriamente deslocamento ou cisão da voz lírica [...] ela não assume o ponto de vista daqueles a quem retrata, nem se instabiliza radicalmente a ponto de prescindir de pausas epifânicas".

Las observaciones de Iumna y de Weintraub se pueden localizar en "Indisciplina". El poema está planteado como una parodia crítica del espectáculo de los desfiles de moda que acaba siendo el espectáculo de la miseria. El yo lírico permanece oculto entre las descripciones llanas u "objetivas" ("no meio do tumulto dos carros e ônibus") y las paródicas ("fumando à la Eloise / ostensivamente"), y sólo se manifiesta en los sutiles juicios de valor que operan mediante el contraste de las realidades confrontadas. La "pausa epifânica" podría localizarse en el penúltimo verso, "sob o sol de cada dia", como preparación para el cierre irónico. Me parece acertada la lectura que Weintraub hace del poema "Prosa" como indicio de una parte fundamental de la poética del libro: el lugar del yo lírico. Es verdad que Bonvicino se postula como "fabricante de algo que não se vende" pero, en realidad, el poema comienza con una comparación: "Um poema não se vende como música, não se vende como quadro, como canção, ninguém dá um centavo [...]". Esto puede ser interpretado de dos maneras: 1) como lo hace Weintraub, es decir, la poesía no se vende, y punto; y 2) la poesía no se vende como la música, la pintura, la canción, etc., lo cual apunta al tópico común de que la poesía, por no haberse mercantilizado tan fácilmente (dado su naturaleza refractaria a este proceso, la cual tiene que ver con que se exija a sus lectores una preparación especial), es el último bastión del arte, que se ha mantenido incorruptible, hasta cierto punto. En el primer caso, el carácter heroico de la resistencia del poeta es una consecuencia pura de su voluntad; en el segundo, es también una secuela de la naturaleza de la poesía moderna y contemporánea. No obstante esta diferencia, concuerdo en que la autopresentación como "mau negociante de inutilidades" conserva la pureza del pathos del primer sentido. Por ello, la frase que sigue a esta última y 
que cierra el poema - "me tenha impregnado da praga das palavras" - recibe de Weintrab la lectura de que el poeta es "portador da redentora "praga das palavras", cuando cabría la posibilidad de interpretarla pensando en el poeta como condenado a padecer la maldición de trabajar con las palabras. ${ }^{27}$ Esta última interpretación podría estar entre las intenciones originales del autor, aunque el tono "judicativo", de "reprimenda" - identificado por Weintraub en otros poemas - sea el dominante en el libro, lo cual no sorprende, dígase de paso, ya que el autor ejerce la profesión de juez.

La idea de la "redentora praga das palavras" otorga un papel activo y protagónico a la poesía, aunque sea meramente como portaestandarte de conciencia moral. En ese sentido, por su gesto de denuncia, recuerda la época de la poesía comprometida, aunque sin el horizonte utópico ni el entusiasmo para emprender una acción efectiva de cambio, porque no parece haber lugar para ello. De ahí la "militância imaginâria" mencionada por Iumna y el reclamo que hace por la falta de articulación de las imágenes del horror económico. Siguiendo las ideas de Perrone, este reclamo implica que el poeta cree aún en los poderes transformadores de la poesía y siente ese "deseo de participar", pero se presenta a sí mismo como "atado de manos" al limitarse a describir la debacle.

A mi modo de ver, señalar este handicap de Página orfã no es pedir que incluya una "solución", una reflexión moral o un análisis sociopolítico de la realidad que exhibe. Es sugerir que falta la visión desde el otro lado, lo que Iumna llama "sufrimiento de la intersubjetividad", concepto que estaría cerca de la idea de "empatía", o en un tono más neutro, simplemente "intersubjetividad", para cumplir con la intención de mostrar un problema social que tiene por lo menos dos caras. Creo que la promoción de este tipo de mirada de doble vía guarda una fuerte relación con la idea de una "indeterminación identitária", que Flora Sussekind menciona a propósito de la poesía de Sebastião Uchoa Leite. En principio, Sussekind identifica en los poemas de Uchoa Leite un "enmaranhado do self" con "alterrepresentações subjetivas", que da cuenta de la convivencia dramática, autoirónica y en tensión poética, de los diferentes "yoes" del poeta: el "sr. Leite", "um acuado joãocabral / ou um valéry risível”, Bogart, Yves Montand, Delon, "morcego de botequim”, etc. Más adelante, esta convivencia se complementa con la creación de "uma zona transicional entre dentro e fora, poeta e paisagem" que parece reducir las distancias jerárquicas de la observación entre el sujeto y la materia urbana, y permitir la inversión de los papeles entre observador y observado. De ahí que, en la poesía de Uchoa Leite, sea frecuente encontrar "micronarrativas policiacas" en las que hay un clima generalizado de sospecha, duda y persecución identitaria. No en balde uno de sus poemas lleva por título "Vida é arte paranóica" y otro, "Os assassinos e as vítimas", desarrolla la "metáfora de la persecución" en el contexto cinematográfico. ${ }^{28}$ En este último poema, varios personajes de películas juegan roles de perseguidor o perseguido, asesino o víctima, según sea el caso y el momento de la historia. Por ejemplo, los primeros versos hacen referencia a El Halcón Maltés: "eu bogart / decifro o falcão maltês / mas sou tragado por você mary astor". Sabemos que el detective privado Sam Spade, actuado por Humphrey Bogart en la película, es buscado por la enigmática Ruth Wonderly, actuada por Mary Astor, para que busque a su desaparecida hermana. Bogart logrará desentrañar el misterio de la valiosa estatuilla, en una compleja trama, pero finalmente se dará cuenta que Mary Astor, de quien se ha prendado, le ha mentido y es en realidad una criminal. Así, él pasa de perseguidor a víctima y ella, de víctima (por la desaparición de su hermana) a criminal. 
Un flujo de roles similar sucede entre el yo poético y el paisaje (la "zona transicional" señalada por Sussekind) en el breve poema "Numa incerta noite" que narra un traslado en ambulancia contemplado desde las ventanas del vehículo: "Calculo as ruas que atravesso / Vendo a copa das árvores / Guiado pelas folhagens / Profusamente imerso / Na vertigem inversa / Da hemorragia verde / Do ciclópico olho vegetal / Que me contempla". ${ }^{29}$ El sujeto mira pero a la vez es mirado por el "ciclópeo olho vegetal". El ejemplo que mejor ilustra este flujo de roles en el contexto de la miseria urbana es el poema "O sobrevivente", pues retrata, en las calles de Rio de Janeiro, la figura de una indigente:

\section{O SOBREVIVENTE}

Outras vezes se passa

$\mathrm{Na}$ Azeredo Coutinho

E ali vê-se

Outro espécime

Da "humanidade de cócoras"

(Marcel Mauss)

Uma louca

Discute consigo mesma

Hamlet aos brados

(“Ó minh’alma profética!”)

Rápido contorno

Este "ser ali"

En alto regozijo

Do meu perfeito juizo ${ }^{30}$

La loca en cuclillas que habla consigo misma, desde la controvertida posición de descanso estudiada por Marcel Mauss, es vista por el paseante citadino como la figura de un Hamlet que grita el verso tomado de la pieza shakespeareana. Después de rodear al "ser ali" (alusión oblicua al Dasein heideggeriano), el sujeto poético que parece escapar dice regocijarse de su perfecta cordura, observación que, en su llana ingenuidad, se relativiza a sí misma por la mera presencia del "espécimen" observado que lo cuestiona. Además, es necesario recordar que Hamlet exclama "Oh, my prophetic soul!" cuando ve el fantasma de su padre y refuerza, con esa visión, las sospechas de que fue asesinado. También es importante señalar que, a lo largo del drama, en algunas ocasiones Hamlet es considerado loco, mientras que en otras se finge loco. Esto desestabiliza aún más el "perfeito juizo" del paseante pues la loca del poema, al igual que el personaje de Shakespeare, puede saber una verdad entregada por su "alma profética" que no es evidente para los demás. Desde luego, estamos ante una inversión de papeles mucho más compleja que la que aparece en "Numa incerta noite", presentada de manera gramatical por los verbos "ver" y "ser contemplado".

Esta circulación de la mirada es más fácil de hallar en "Barrabás" que en "Indisciplina". Como ya mencioné, el yo-lírico en "Barrabás" se identifica con la viuda, el primer "vocês" señala a los encargados de la funeraria y el segundo a los deudos del bandido. Sin embargo, no 
está ausente en "Indisciplina": se encuentra en los veladamente amenazantes versos "fecha a bolsa / acabe com o jogo", al parecer proferidos por algún asaltante. Sin embargo, no llega a integrar un clima de intersubjetividad. Creo que esto se debe a lo que llamé "asepsia sentimental", que no deja de estar relacionada con lo que Iumna llama "rarefacción referencial" - a propósito del manierismo provocado por la "retradicionalización" -, y con la "ansiedad referencial" que la misma autora señala en la poesía de Claudia Roquette-Pinto y que puede entenderse a la vez como un reflejo de la rarefacción en el sujeto lírico o como un recurso estético usado en la composición. ${ }^{31}$

Respecto al "retorno de lo real", primero me parece necesario entenderlo como un "retorno de lo reprimido" en el contexto de la poesía brasileña, el cual he tratado de esbozar, en lo posible, apoyándome en Perrone, Iumna y Sussekind. En ese sentido, es tanto lo "real" (la realidad colectiva, social) como lo sentimental (lo oculto u obliterado por la "asepsia sentimental") lo que ha estado ausente y ahora regresa. La propuesta central que aparece en The Return of the Real (1996) de Hal Foster -obra en la cual, como lo señala Weintraub, se inspiró Iumna para escribir su artículo- se basa también en este concepto psicoanalítico, situado en el ámbito de la "guerra de la abstracción contra la representación" en las artes plásticas, a partir del minimalismo. ${ }^{32} \mathrm{El}$ resumen que Weintraub hace de la tesis de Foster permite distinguir cuál es la idea de realismo involucrada:

\begin{abstract}
Relendo a história das vanguardas no campo das artes plásticas, Foster identifica uma mudança, sobretudo com base em obras feitas na última década do século XX, marcada por experiências de abjeção e violência extremas, uma transformação no conceito de realismo, o qual passa a ser compreendido menos como efeito de uma representação e mais como evento traumático, força de interrupção sobre o vínculo do espectador com um real outrora pacificado e encoberto pela mediação simbólica e imaginária do regime representacional. Trata-se de um real em acepção psicoanalítico-lacaniana, o real como o que resiste à simbolização e cuja emergência é fonte de angústia. Sua repetição compulsiva não equivaleria exclusivamente nem à representação de um referente nem à simulação de uma imagem, diferenciando-se, por conseguinte, tanto do modelo referencial como do modelo autorreferencial inerente à noção de simulacro. A novidade das representações contemporâneas, para Foster, estaria no fato de elas serem, ao mesmo tempo, referenciais e simulacrais, forjando imagens simultaneamente conectadas à realidade e delas desconectadas, imagens ao mesmo tempo reais e artificiais. ${ }^{33}$
\end{abstract}

Como se puede apreciar, para Foster "el retorno de lo real" se efectúa a través de un realismo traumático. Es decir, siguiendo la etimología del adjetivo - y glosando las propias palabras de Foster-, se trata de un realismo "de herida" que ataca justo una "pantalla-tamiz" (screen), la cual media entre el sujeto y lo real, siendo lo real algo que se resiste a la representación. ${ }^{34}$ La pantalla-tamiz filtra y así parcialmente orienta el resultado hacia la representación simbólica de un referente o hacia la presentificación de un simulacro autorreferente, dependiendo de la aproximación llevada a cabo por el sujeto. Esta oscilación (o quizás simultaneidad, como dice Weintraub) es ejemplificada por Foster con ayuda de algunas obras, entre ellas dos de Andy Warhol basadas en fotografías y pertenecientes a la serie "Death in America": Ambulance Disaster (1963), fotografía estampada en serigrafía dos veces, en la que un cuerpo cuelga de la ventana de una ambulancia chocada, y White Burning Car III (1963), fotografía estampada cinco veces en la que un auto volcado y en llamas está flanqueado a la izquierda por un cuerpo colgado en un poste, mientras en perspectiva al fondo se ve pasar a un caminante. 


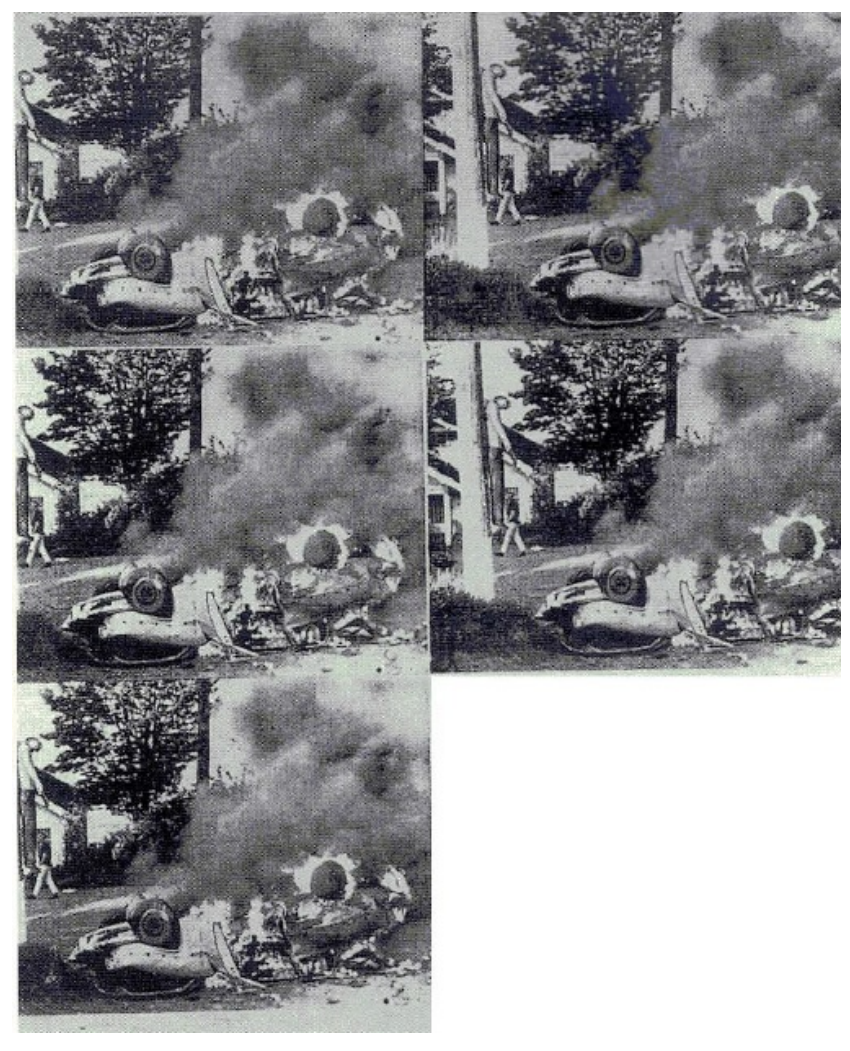

White Burning Car III (1963)

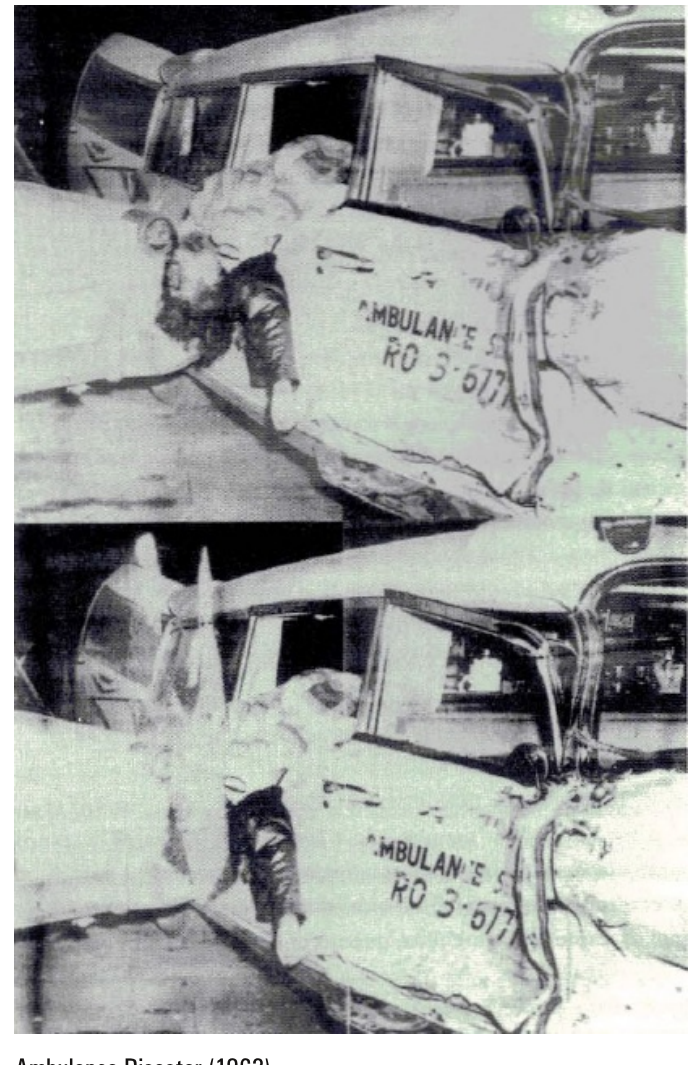

Ambulance Disaster (1963)

Foster explica que en esas obras la repetición no es reproducción. Si Lacan define lo traumático como un "encuentro fallido con lo real", es porque lo real no puede ser representado sino repetido $\mathrm{y}$, de hecho, debe ser repetido - como se verá más adelante - como una estrategia de protección o "defensa apotropaica". ${ }^{35} \mathrm{Al}$ referirse a estos casos, Foster dice:

no es reproducción en el sentido de representación (de un referente) o simulación (de una imagen pura, un significante desvinculado). Más bien, la repetición sirve para tamizar lo real entendido como traumático. Pero su misma necesidad apunta asimismo a lo real, y en ese punto la repetición rompe la pantalla-tamiz de la repetición. Es una ruptura no tanto en el mundo como en el sujeto, entre la percepción y la conciencia de un sujeto tocado por una imagen". ${ }^{36}$

Así, Ambulance disaster no representa el desastre real del accidente pero tampoco está totalmente desvinculado de él y de lo que pudiera significar la realidad traumática de donde viene. No es una imagen pura, un simulacro, una "realidad independiente", ni pretende serlo. Tamiza lo real pero al hacerlo, la mera necesidad ansiosa de hacerlo implica que lo real, lo que amenaza, se ha "filtrado", ha roto la pantalla-tamiz en ese punto. Por ello, Foster ubica esa ruptura, en principio, en el sujeto, entre la percepción fallida y la conciencia, pero después modula esta localización y dice que es una confusión del sujeto y el mundo, el dentro y el fuera, y sugiere que quizá la propia confusión sea lo traumático. Foster observa que Lacan llama tuché a ese punto traumático y que Barthes, en su libro Camera lucida, lo designa punctum y lo describe así: "Es lo que yo añado a la fotografía y lo que, sin embargo, está ya en ella". ${ }^{37}$ Foster hace una precisión más al señalar que Barthes se ocupa de las fotografías sin aditivos y que, por ejemplo, en White Burning Car III hay un punctum en la indiferencia del transeúnte hacia la víctima colgada en el poste, pues esta indiferencia, deduzco, puede 
provenir de lo real, ser histórica (la persona, si fuera entrevistada, declararía que pasó indiferente), puede generarse en la lectura del "sujeto tocado por la imagen", o puede haber estado entre las intenciones del fotógrafo. Sin embargo, en el caso de Warhol hay, dice Foster, una "operación general del punctum" que funciona menos por el contenido que por la propia repetición y por la técnica, ya que en el proceso de serigrafía el autor agregó "destellos flotantes", rayados, blanqueados, coloración y repetición, entre otras cosas, al auto en llamas. Así, también en Ambulance Disaster Foster encuentra un punctum no en la imagen original del cuerpo colgando de la ventana, sino en la "obscena" lágrima superpuesta que cubre todo su rostro, como si hubiera caído, gigantesca, sobre la fotografía. Es decir, habría dos maneras al menos en que los puncta se suscitan. En este proceso, la figura del autor también adquiere una dimensión ambigua pues fluctúa entre la actitud maquinal de mero presentador de una superficie y la tradicional presencia tras la obra que irradia una intención y es capaz de suscitar empatía con el observador. Asimismo, en estas imágenes "a la vez afectivas y desafectas", el observador oscila entre un sujeto que no está integrado sino que es compuesto en la contemplación - "ideal de la estética más moderna", dice Foster - y un sujeto que está disuelto, como sucede en gran parte de la cultura popular, en que hay una "entrega a las intensidades esquizo del signo-mercancía". ${ }^{38}$

Ha sido necesario entrar en todo este detalle para subrayar, en aparente digresión, que, si la idea de realidad que ha estado en juego en el campo de las artes plásticas, desde la perspectiva de la "guerra de la abstracción contra la representación", es compleja, su trasposición hacia el campo de la poesía debe reflejar esa complejidad. No obstante, integrarla en mi recorrido excedería los propósitos iniciales de este escrito por lo que me limitaré a tratar de señalar algunos paralelos con lo que antes expuse, teniendo en mente esa trasposición. En principio, la "guerra de la abstracción contra la representación" puede tener su correlato en algunos rasgos señalados por Iumna como parte del proceso de "retradicionalización" en la poesía brasileña contemporánea: "rigor constructivo", "escritura abstracta", "rarefacción referencial", "indeterminación discursiva", "oscurecimiento del asunto", "ansiedad referencial", etc. Desde luego, en este cuadro cabría también la posibilidad de ver la idea de simulacro como relacionada con la aspiración del concretismo a hacer del poema un objeto verbivocovisual, subrayando su materialidad. Por otra parte, la "persecución identitaria", la sensación de sentirse observado por las cosas o las personas, el clima paranoico y la circulación de la mirada - rasgos todos apuntados como sobresalientes en la poesía de Uchoa Leite - pueden tener una conexión fuerte con la idea de un "realismo traumático". En una de las derivaciones del desarrollo de este concepto, Foster añade al esquema que brevemente describí un énfasis en la idea lacaniana de que a la acción que lleva a cabo el sujeto al mirar a través de la pantalla-tamiz corresponde una sensación de ser mirado por lo real: "esta pantallatamiz media la mirada del objeto para el sujeto, pero también protege al sujeto de esta mirada del objeto". ${ }^{39}$ La mediación es necesaria porque de lo contrario el sujeto sería cegado por esa mirada o tocado por lo real. De esta manera se conjugan dos ideas centrales que Foster maneja, repetición y retorno, pues si la repetición tiene su lado de exorcismo tamizante de la realidad traumática, ésta retorna "accidental y/o oblicuamente" en el mismo tamizado. La mirada intenta atrapar al sujeto mientras éste procura domarla, escenario general en que se crean cuadros paranoides. Lacan imagina la mirada como algo un tanto maléfico por lo que la llama 
"el ojo del diablo". ${ }^{40}$ Algo de esta situación inquietante se puede encontrar específicamente en el "ciclópico olho vegetal" del poema "Numa incerta noite" de Uchoa Leite, y de manera general en el título de uno de sus libros, A espreita (2000), "el acecho", que dibuja un yo poético de características afines.

El caso de "Indisciplina" se ve iluminado por el concepto de "realismo traumático" de Foster, desde la perspectiva del autor en actitud maquinal de presentador de una superficie, y de la obra como un simulacro. Desde luego, en esto hay distancias importantes entre las artes plásticas y la literatura que son insalvables. Como bien observa Karl Erik Schøllhammer:

Contrário às artes plásticas, disse Jakobson, a literatura representativa não chega a
criar uma convençã̃o sólida de descrição do objeto como acontece, por exempli, na
imagem com o perspectivismo que fornece uma tradução universal quase automática
das três dimensões em duas. A linguagem nunca consegue criar uma cópia sensível
do real e, diferente do ilusionismo visual, não corre o perigo de ser confundida com
seu objeto. ${ }^{41}$

Por ello, por ejemplo, no hay un lugar en la literatura que sea paralelo al que ocupa la fotografía en las artes plásticas, ni tampoco pueden existir en la literatura los problemas que plantea el hiperrrealismo en las artes plásticas.

No obstante estas limitaciones, la "objetividad ostensiva" señalada por Iumna y la ausencia de una "simpatía social" podrían integrar la mencionada visión de simulacro en "Indisciplina". La crítica negativa acerca de que Bonvicino presenta como espectáculo las imágenes desarticuladas del horror económico quedaría sin posible efecto, porque es justamente la presentación "anodina" una marca distintiva de esta visión. Tampoco se podría reclamar que hubiera en el poema, como quiere Weintraub, una "cisão da voz lírica", porque tal reclamo caería igualmente fuera del esquema. El problema para integrar esta visión proviene de que la "actitud imperturbable" del autor - Foster se refiere así a la postura de Warhol - no se sostiene. La falla de esta actitud es difícil de ubicar en el poema aislado y tal vez pudiera encontrarse en lo que Weintraub llama "pausa epifânica", donde podría localizarse una intención del yo lírico. ${ }^{42}$ Sin embargo, la identificación de esta "pausa epifânica" sólo ha sido posible después de distinguir un patrón que se repite no sólo en Página orfã sino también en libros anteriores del autor. O sea, no proviene del poema aislado sino del conjunto. Así también, la ruptura de la distancia que el artista debería mantener en estos casos sucede fuera de "Indisciplina", en el poema "Prosa", como ya mencioné, cuando aparece la figura del "mau negociante de inutilidades". Es decir, cuando el yo lírico adopta una postura acerca de lo que se muestra en el conjunto de poemas a través de un personaje que encarna un imagen romántica de la poesía y que puede entenderse también como autoimagen del autor. Desaparece la "dosis de asubjetividad" que, siguiendo a Foster, parece indispensable en estos casos para infligir la duda "fascinante" acerca de si hay o no "alguien" detrás del objeto presentado. ${ }^{43}$

En el caso de Fabio Weintraub, el carácter referencial de "Barrabás" es muy evidente y el retorno de lo real se da de manera simple, como lo describí hace unos párrafos. Se trata de un "retorno de lo reprimido" como retorno de lo que había estado ausente de la poesía brasileña. Su faceta "simulacral" no se encuentra ahí, pero la podríamos hallar, como ya mencioné, en poemas con otras estrategias retóricas como "Love me tender", construidos a base de montaje de frases, datos, "cápsulas informativas", tras de los cuales se oculta el yo- 
lírico en una "actitud imperturbable". En poemas que no tienen esta estructura, la posible identificación de esta actitud en el yo-lírico se diluye tras la circulación de la mirada, la empatía con los personajes y la presentación del "sufrimiento de la intersubjetividad" en una suerte de teatro. No existe ninguna figura parecida al "mau negociante de inutilidades". El "realismo traumático" entra a través del juego de voces de los personajes.

En cuanto a "Sitio" de Claudia Roquette-Pinto, la posibilidad de una visión simulacral es viable, pues el poema está armado como un montaje de escenas narradas de manera impersonal por un sujeto indefinido, que no se deja asir del todo, aunque es posible señalar algunas de sus características, como lo ha hecho Iumna al identificar una "ansiedad referencial". ${ }^{44}$ Claro, esto último no parte exclusivamente del poema, sino de análisis más amplios necesarios para la identificación de patrones, como sucede con la "pausa epifânica" en Bonvicino. Quizás la peculiaridad de "Sítio" en esta visión simulacral provenga justamente de un yo lírico definido dentro del poema a través de la "ansiedad referencial". Es decir, dibuja un tipo de sujeto angustiado pero impersonal, un sujeto que se oculta y lo poco que se sabe de él es que padece angustia. La realidad traumática entra y produce angustia cuando podría producir otras emociones. Si tomamos como contraste "Barrabás", es posible proponer que la emoción dominante sea la indignación y la rabia, no la angustia y el miedo.

Termino aquí el ejercicio de trasposición de las ideas del "retorno de lo real" de Foster a los ejemplos de poesía brasileña antes expuestos. Un último detalle que quiero enfatizar es que me parece que Iumna aborda el concepto más desde el ángulo del "retorno de lo reprimido" por una tradición en impasse, que desde el cuestionamiento de la representación y del realismo como problema. Como ya cité anteriormente, para ella este retorno se trata de "a volta da referencialidade concreta, do país real, dos problemas sociais, da decadência urbana". ${ }^{45}$ Aunque en su descripción de la retradicionalización de la poesía menciona a la "autonomia esteticista" como algo antiguo e incluso incorporado a la retradicionalización, su reclamo por una recuperación del contenido crítico que tenían las tradiciones modernas pasa por la idea de un enfrentamiento entre ideas como "referencialidade concreta" y "país real" versus ideas como "formas convencionais e auto-referidas" y "autonomia poética". Este enfrentamiento, aunque útil para señalar los desgastes del medio poético y los impasses manieristas de sus distintas vertientes, parece revivir el antiguo debate de la autonomía esteticista, asunto hoy francamente cuestionable por las complejidades que trae intentar establecer una vinculación simple de la producción poética con la realidad o, mejor dicho, con los realismos y todos sus problemas. Si consideramos el vaivén de las representaciones contemporáneas entre lo referencial y lo simulacral, es difícil plantear una autonomía estética.

Por último, quiero mencionar brevemente al poeta Fabrício Carpinejar (1972), quien ha venido desarrollando una dicción "humana", próxima al "ciudadano común", que busca retratar no sólo el lado sórdido y trágico de la existencia social, sino también su cara contraria, aquella en que las pequeñas alegrías son posibles, en la dimensión humilde de la vida cotidiana, encarada con solidaridad y fraternidad. Veamos el principio de la "Primera elegía" del libro Terceira sede (2001): 


\section{PRIMEIRA ELEGIA}

Só na velhice conheci o brio

de viver com vagar.

O rostro já não tem mais residência, move-se a cada sorvo das sombras.

Há mais terra debaixo da pele que a terra onde piso.

Atravessei o século e ainda não me percorri.

Qual a senha que transporto?

Serei contrabando de Deus, que vai quieto dentro, receoso de se pronunciar?

Condiciono os amores a uma expectativa.

Mas é justamente ela que me impede ser real.

Tornei-me o diário de uma viagem cancelada.

$$
[\ldots]^{46}
$$

La referencia del título del libro a la "tercera edad" es prácticamente automática. El subtítulo "Elegias" subraya --por la naturaleza del género-- el tono de lamento, y el significado que domina la palabra "sede" es la idea de "asiento", "asentamiento", por sobre la alternativa de entenderla como "sed", aunque esta última opción no quede descartada. ${ }^{47}$ Desde los primeros versos, el posible tono lastimero muestra sus brotes de dignidad y orgullo, pues se trata de una reivindicación de la vejez, ante el culto de la modernidad por lo nuevo, la juventud y el movimiento. Por eso, el poema exhorta los bríos que hay en la vejez y la oportunidad de vivir lentamente, lo cual apoya la interpretación de "sede" como "sed". La idea de residencia, relacionada también con estar en paz y asentado, al ser colocada en forma negativa junto a la de rostro, "un rostro sin residencia", genera una sensación de desapego, de preparación para la muerte. De esta manera, se entiende que haya más tierra bajo la piel que bajo los pies, y los "sorvos de sombras" puedan ser identificados con los recuerdos, cosas volátiles pero muy presentes e incluso más importantes que la tierra que se pisa. El clima filosófico, de recogimiento, va poblando el poema y el sujeto poético se asume inconmensurable --atravesó el siglo y aún no se ha recorrido-- para desembocar en el tema religioso, al preguntar por Dios, por el significado de la existencia. La idea de condicionar el amor a una expectativa es algo totalmente antirromántico, calculador, contrario a la idea del amor desinteresado, pero inmediatamente es situada como impedimento para ser "real". El poema recobra algo de ambigüedad en esos versos porque ser "real" podría equivaler a "ser desinteresado" y, por lo tanto, desprendido, haciendo de la situación un defecto. Sin embargo, esta idea podría ser entendida como una postura desengañada en que las expectativas, lo palpable, es lo que cuenta --después de haber aprendido eso a lo largo de toda una vida-- y ser "real" sería ser 
desinteresado y, por lo tanto, ser ingenuo. El último verso citado da continuidad a la serie simbólica y adopta un tono enfático, melancólico y patético. El poema continúa con la enumeración de situaciones que guardan un significado simbólico y son dichas con un aire sentencioso: "Minha atualidade é ter fome, não evoluímos perante o alimento". Hay ocasiones en que se percibe una búsqueda de profundidad filosófica que roza la meditación ingenua: "Nivelamos a cura ao veneno, / o tempo discrimina sua natureza. / O que chega atrasado ou adiantado envenena. / O que é pontual cura". La pretensión de lo alegórico-simbólico no está ausente -"Não sei absorver a mensagem da troca de guarda / entre a coruja e o melro. Muito menos traduzir / o que sente o cão quando percebe que a ave lacerada / não tinha ossos a compensar o esforço"- ni el lugar común: "Será a fidelidade uma forma de trair?". El poema tiene 47 versos y un cierre con un juego de palabras: "Não me empurrem mais, não vou por onde não sei. / Deixa-me pensar o corpo, deixa o corpo me pensar". ${ }^{48}$ A esta composición seguirán una "Segunda elegia", una tercera, así hasta completar diez poemas de extensión similar.

En un preámbulo escrito en verso, el autor aclara que finge poéticamente tener 72 años: el libro sería de 2045 pero él ha decidido "anticipar su vejez". Los versos iniciales llevan el mismo tono filosófico de la elegía comentada y dan un mayor apoyo al desdoblamiento del autor, un apoyo casi didáctico: "Aquí nada é real. Mas o que é real? / a literatura ou o que escapa da escrita? // A vida relatada, não sendo minha, é mais minha sendo do outro". ${ }^{49} \mathrm{El}$ libro tuvo éxito editorial y entre la crítica, pues fue lanzado en 2001, recibió el Prêmio Nacional Cecília Meireles 2002, de la União Brasileira de Escritores, y tuvo una segunda edición en 2003 (no hay noticia del tiraje). La trayectoria de Carpinejar es singular, con más de veinte libros publicados -varios de ellos premiados- y muy cercana a los medios masivos de comunicación. Periodista con una maestría en literatura brasileña, ha cultivado el género de la crónica de una manera constante en distintos diarios y, desde marzo de 2012, dirige como entrevistador el programa de auditorio A Máquina de la televisora Rede Gazeta. ${ }^{50}$

El caso de Carpinejar es interesante no por el éxito con que logra travestirse de un poeta de 72 años, sino por el hecho mismo de formular el proyecto. Me parece que Terceira sede apunta a la importantísima faceta de la realidad social que es la existencia de los viejos (aspecto también tocado por Weintraub), pero también al sector del mercado literario que constituyen, pues a la peculiaridad de intentar tratar el tema desde adentro se suma la de abordarlo de manera exclusiva -el libro está dedicado integralmente al tema- y exhaustiva: entre los subtemas están los recuerdos, los sueños no alcanzados, la decadencia del cuerpo, la viudez, la soledad, el desempleo, la transformaciones del amor y la pasión, la vergüenza del entorpecimiento físico, la pérdida de la memoria, etc.

Lo señalado en estos últimos párrafos permite vislumbrar cómo la reinserción de la realidad social en la producción poética brasileña actual también puede pasar por los medios masivos de comunicación y recibir una influencia de ellos. El entrevistador Carpinejar no deja de ser el poeta Carpinejar y viceversa. Desde luego, esta incursión en los medios televisivos es posterior a la escritura de Terceira sede, pero me parece que la poética que Carpinejar venía desarrollando desde antes aspiraba a tener una expansión masiva a través de la idea del "hombre común", del poeta no como un "ser fuera de serie" y al que es posible acercarse sólo mediante una "iniciación". Tiene algo de espíritu democrático. Como apunta Manuel da Costa 
Pinto, Carpinejar es un "poeta pessoano", en el sentido de que incluye una inquietud metafísica, pero es ajeno a valores como transgresión, ampliación del repertorio de formas, experimentación, etc. En cambio, su impacto se debe a la búsqueda de una espontaneidad y una conmoción interior que redundan en una poesía emotiva y confesional, controlada por referencias a situaciones del hombre común, en las cuales descubre aspectos dramáticos así como puntos de partida para elaboraciones más abstractas. ${ }^{51}$

Aunque Terceira sede sea un libro dirigido a los viejos, como dije anteriormente, por ser un público que la poesía brasileña había relegado, esto no descarta que se deba también a un desafío personal que el poeta se impuso -escribir imaginando el propio yo-poético proyectado en el futuro- y que esto puede ser visto como un gesto "innovador" por la crítica que está atenta a este tipo de búsquedas. ${ }^{52}$ Por otra parte, esta misma proyección cumpliría con las ideas expuestas de "circulación de la mirada" e "intersubjetividad", pues el poeta habría recogido de su entorno parte de las experiencias que plasma en cada una de las elegías, además de seguir su propia guía imaginativa y experiencia personal. Esta búsqueda de empatía, no obstante, creo que encuentra algunos obstáculos. A la vez que mantiene un tono filosófico y trata de ser abarcante, no sólo no rehúye el lugar común sino que parece procurarlo. Hay que recordar también que se apoya en el género de la elegía y que cada poema es una mezcla de sentencias tejidas con narrativas de corte metafórico y simbólico en un peculiar fluir fragmentario. Es decir, el autor no es ingenuo en su búsqueda y es justo ahí donde surge la pregunta: ¿Estamos hablando de "lugar común" para quién? Para el público lego, que puede entender la poesía, por ejemplo, como algo que "eleva el espíritu", los supuestos lugares comunes pueden resultar ser verdades morales valiosas expresadas llanamente, sin oscuridades. En el caso de la crítica se dan otras posturas. Para un crítico especializado, que se inclina por la complejidad que adquirió la poesía después de la modernidad y las vanguardias, pueden parecer truismos o, como dije anteriormente, productos de una máscara, de la proyección de un "yo". Sin embargo, para un crítico conservador, pueden significar un regreso a la sencillez, a la claridad, al modo directo de expresar que la poesía tenía y perdió, visión que también se sustenta en la elección de un género clásico como la elegía. Desde luego, estoy hablando de posiciones extremas, cuando lo que realmente sucede es un vaivén entre ellas. Por un lado puede surgir la pregunta: ¿El poeta no habrá simplificado demasiado su discurso? Pero en el opuesto, aparecen otras: ¿Se está queriendo hallar complejidad donde no la hay? o ¿La simplicidad acaso no esconde sutilmente una complejidad ${ }^{53}$

Esta situación señala una inestabilidad en la percepción de la figura tras el texto y, a la vez, hace surgir la necesidad de una mayor precisión. En Terceira sede lo que fluctúa no es el yo-poético sino el "autor implícito", es decir, la figura del autor que el lector construye a partir de su lectura. Se trata de quien construyó el texto, mediante determinadas habilidades e intenciones cuya percepción depende de las habilidades críticas del lector. No es la voz que enuncia el texto, la cual tiene más una calidad de "personaje" dentro del texto. Me parece que si volvemos al ejemplo de Bonvicino, el matiz que marca la diferencia entre estas dos figuras podría vislumbrarse mejor: la figura del "mau negociante de inutilidades" correspondería al yo-poético, mientras que el autor implícito sería aquél que con sus habilidades poéticas construyó la "objetividad ostensiva", la "violência antidiscursiva" que menciona Iumna. En el caso específico de "Indisciplina", el autor implícito sería también este último mientras que el 
yo-poético estaría ocultándose. En Terceira sede se puede formular una cierta uniformidad en el yo poético, en el sentido de que hay una voz, la del poeta proyectado en el futuro año de 2045, que adopta una serie de posturas filosóficas y morales que le dan unidad y producen empatía en el lector.

Como último punto, me gustaría volver a la idea del "retorno de lo real" introducida por Iumna, problema que traté inicialmente como "reinserción de la realidad social en la producción poética brasileña". En el caso de Terceira sede, sucede como un "retorno de lo reprimido", en el sentido de una emotividad confesional liberada de la presión de la "asepsia sentimental". Siguiendo la dicotomía entre lo referencial y lo simulacral, es posible afirmar que el libro de Carpinejar es totalmente referencial y no es posible hacer una lectura simulacral. No hay la más mínima posibilidad de identificar una "actitud imperturbable" por parte del autor. Al contrario, hay una intención que constantemente se manifiesta. Si Foster identifica una fluctuación entre lo simulacral y lo referencial que da lugar a un retorno de la realidad a través del "realismo traumático", en el caso de Terceira sede este retorno sucede a través de un realismo que incluye de manera fuerte a los medios masivos de comunicación. Como he tratado de mostrar, sería muy difícil deslindar a Terceira sede del proyecto de impacto masivo que lo sustenta y también sería problemático tratar de considerar una realidad con un público amplio para la poesía brasileña que no estuviera afectada por los medios masivos de comunicación. Si Iumna reclama un regreso a la "referencialidad concreta, del país real, de los problemas sociales", en esta referencialidad, en esta vehiculación de lo real, también están presentes los medios masivos de comunicación y su lógica de mercado y consumo. No con esto quiero decir que Terceira sede se "rebaje" a pactar un "adelgazamiento" de sus contenidos y sus medios retóricos, es decir, de su poética, sino que busca un difícil equilibrio que estaría retomando la utopía vanguardista de "reintegrar el arte a la praxis social". Tampoco quiero decir que lo logre, pero en la fluctuación del "autor implícito" que señalé se encuentra un indicio importante de que atiende a varios públicos a la vez.

Termino aquí la revisión que me he planteado hacer de algunos ejemplos de la reciente producción poética brasileña de corte social y político. Los únicos rasgos que perviven de la poesía comprometida de los años 60 y 70 son la tendencia a propiciar, alrededor de un yopoético romántico de emotividad impostada, un clima de pathos dramático. Aunque de manera subterránea, esto parece estar presente en algunos poemas de Bonvicino. El contenido ideológico está ausente, así como la actitud didáctica y la idea de la poesía como vehículo que cumple una función. El "retorno de lo real", concepto desarrollado por Iumna para superar el impasse de la crisis de la retradicionalización de la poesía --desgaste del poder crítico de la poesía por cuenta de la incorporación de formas autorreferidas-- mostró tener una interpretación llana como "retorno de lo reprimido". Sin embargo, considerado de una manera más cercana a lo planteado por Foster ("visión referencial" y "visión simulacral"), adquirió desdoblamientos que permitieron, con apoyo del concepto de "indeterminação identitária", de Sussekind, y la idea de una mirada que circula, mejores apreciaciones de las figuraciones del yo-poético y del autor implícito. Asimismo, el caso especial de Carpinejar, como figura literario-mediática, permitió adicionar a la idea de "reinserción de la realidad social", la parcela que los medios tienen dentro de ella y su importantísimo papel. 


\section{Referencia bibliográfica}

ALVIM, Francisco. Poemas [1968-2000]. São Paulo: Cosac \& Naify, 2004, 391 pp.

AZEVEDo, Carlito. Monodrama, de sítio. Rio de Janeiro: 7Letras, 2009, 152 pp.

Sublunar (1991-2001). Rio de Janeiro: 7Letras, 2001, 100 pp.

BONVICINO, Régis. Estado de sítio. São Paulo: Hedra, 2013, 113 pp.

Página órfã. São Paulo: Martins Fontes, 2007, 133 pp.

BUARQUE de Hollanda. Heloísa, Impressões de viagem: CPC, vanguarda e desbunde: 1960/70, $2^{\text {a }}$ ed., Editora

Brasiliense, 1981, 199 pp.

CAMPos, Augusto de, Décio Pignatari y Haroldo de Campos. Teoria da poesia concreta. Textos críticos e manifestos 1950-1960, 1a ed. São Paulo: Livraria Duas Cidades, 1975, 207 pp.

CAMPos, Haroldo de. "A poesia concreta e a realidade nacional". In: Tendência no. 4, Belo Horizonte: Imp.

Univ. Federal Minas Gerais, 1962, pp. 83-94.

CARPINEJAR, Fabricio. Terceira sede. Elegias, 2a ${ }^{\text {a }}$ ed. São Paulo: Escrituras, 2003, 79 pp.

Costa Pinto, Manuel da. Antologia comentada da poesia brasileira do século 21. São Paulo: Publifolha,

2006, $382 \mathrm{pp}$.

DRUMMOnd de Andrade, Carlos. Poesia completa. Rio de Janeiro: Nova Aguilar, 2002, 1599 pp.

FOSTER, Hal. El retorno de lo real: la vanguardia a finales de siglo. Trad. Alfredo Brotons MUÑOz, Ediciones Akal, Madrid, 2001, 234 pp.

MARTINS, Alberto. Cais. São Paulo: Editora 34, 2002, 123 pp. (Con grabados del autor)

MENDONÇA Teles, Gilberto. Vanguarda européia e modernismo brasileiro. 9a ed. Petrópolis: Editora Vozes, 1986, 448 pp.

PERrone, Charles A. Seven Faces: Brazilian Poetry since Modernism. Durham: Durham \& London Duke-

University Press, 1996, 234 pp.

RoQuetTe-PINTO, Claudia. Margem de manobra. Rio de Janeiro: Aeroplano. 87 pp.

SANDMANN, Marcelo, "Poesia em estado de sítio”. In: Sebastião, 2002-02, pp. 82-87. 165.

SIMON, Iumna Maria, "Situação de Sítio". In: Novos Estudos. São Paulo, no. 82, novembro 2008, pp. 151$215-235$

SIMON, Iumna Maria, “Consistência de Corola”. In: Novos Estudos, São Paulo, no. 85, novembro 2009, pp.

SCHøLLHAMMER, Karl Erik, "Realismo afetivo: evocar realismo além da representação". In: Estudos de Literatura Brasileira Contemporânea, no 39, jan/jun 2012, p. 129-148.

SUSSEKIND, Flora, "Desterritorialização e forma literária. Literatura brasileira contemporânea e experiência urbana”. In: Literatura e Sociedade, São Paulo, no. 8, 2005, pp. 60-81.

VIOLÃO DE RUA I. Rio de Janeiro: Editora Civilização Brasileira, 1962, 92 pp.

Consultado en

http://revistaestudospoliticos.com/wp-content/uploads/2014/04/Violao_de_rua_vol_I.pdf

VIOLÃo DE RUA II, Editora Civilização Brasileira, Rio de Janeiro, 1962, 113 pp. Consultado en

http://revistaestudospoliticos.com/wp-content/uploads/2014/04/Violao_de_rua_Vol_II.pdf

WeInTRAub, Fabio. Baque. São Paulo: Editora 34, 2007, 67 pp. Novo endereço. São Paulo: Nankin-Funalfa, 2002, 71 pp.

"O tiro, o freio, o mendigo e o outdoor: representações do espaço urbano na poesia brasileira pós$1990 \%$. Universidade de São Paulo, Departamento de Teoria Literária e Literatura Comparada, São Paulo, 2013, $203 \mathrm{pp}$. 


\section{Notas de fim}

${ }^{1}$ Cf. Charles Perrone, Seven Faces. Brazilian Poetry since Modernism, pp. 67-72.

${ }^{2}$ Cf. ibid, pp. 72-74.

${ }^{3}$ Los poemas de cordel equivalen aproximadamente a los romances de la tradición española o a los corridos de la tradición

mexicana.

4 Cf. Violão de Rua I, pp. 20-35.

5 [La meta física // A los que hacen volutas de disparates del ser / les pregunto: / --_Qué va a ser / de los 130,000 niños sin escuela / en la principal ciudad del país? / A los que indagan los fines de la existencia / les pregunto: / -¿Cuánta gente hay en el país / sin medios de subsistencia? / A los que disputan entre la eternidad y la hora / les pregunto: / --¿Y ahora?] Cf. Violão de Rua I, pp. 20-35.

${ }^{6}$ Las primeras líneas de "José" muestran al personaje en una encrucijada existencial que, a pesar de ser de índole muy personal, incluye lo colectivo en el fracaso de la utopía: "E agora, José? / A festa acabou, / a luz apagou, / o povo sumiu, / a noite esfriou, / e agora, José? / e agora, vocế? / você que é sem nome, / que zomba dos outros, / você que faz versos, / que ama, protesta? / e agora, José? // Está sem mulher, / está sem discurso, / está sem carinhọ, / já nã̃o pode bẹber, / já nâo pode fưmar, / cuspir já não pode, / a noite esfriou, / o dia não veio, / o bonde não veio, $/$ o riso não veio, / não veio a utopia / e tudo acabou / e tudo fugiu / e tudo mofou, / e agora, José? [...]". 7 Cf. Heloísa Buarque de Hollanda, 26 poeta hoje, pp. 11-12.

8 [Muchas gracias // Al entrar en la oficina / lo saludé con tres palabras / buenas tardes señor / Me senté frente a él / (como me pidió que lo hiciera) / Bonita vista / qué pẹna que nunca la aviste / Recogiendo mi sangre: la aguja / metida en la punta del dedo / va a buscar la vena casi en el sobaco / Discutir el asunto / fuma de mi cigarro / déjame probar el tuyo / (¿Cuánto ganará este tipo?) / Saco, medalla, el país girando / en el hábito del anillo profesional / Al fin y al cabo, mi viejo, son treinta años / hoy como ayer a mediodía / Una copia de este documento / que te entrego en confianza / Tu experiencia nos puede ser muy útil / no es ninguna molestia / cuando quieras estamos aquí]

${ }^{9}$ [Sólo de los terratenientes // no tengo ninguna observación / que hacer sobre la vista de la veranda. / ninguna, / a no ser el cielo amplio e iluminado $/$ de los suburbios de rio de janeiro. / cielo q se estira a lo largo del mundo entero. / no es de todo mundo la tierra q es redonda].

${ }^{10}$ [Revolución // Antes de la revolución yo era profesor / Con ella vino el despido de la Universidad / Empecé a exigir posiciones, de mí y de los demás / (mis padres eran marxistas) / Mejoré mucho -- / hoy ya no me maltrato / ni a mi ni a nadie].

11 Heloísa Buarque de Hollanda, Impressões de viagem: CPC, vanguarda e desbunde: 1960/70, p. 37.

12 En Tendência, no. 4, pp. 83-94.

13 Cf. Gilberto Mandonça Teles, Vanguarda européia e modernismo brasileiro, pp. 406-416.

14 Podría alegarse que una excepción a esta línea fue la difusión de la conciencia de que tanto el slogan, como el diseño gráfico de la propaganda y las letras de la música popular, entre otros elementos relacionados con la cultura de masas y la mercadotecnia, se hallaban vinculados con el quehacer poético.

${ }_{15}$ Cf. Álvaro Lins, "A Rosa do povo", in Jornal de Crítica, José Olympo Editora, Rio de Janeiro, 1947, pp. 8385 , apud Carlos Drummond de Andrade, Poesia completa, p. XLVII.

16 [Sitio // El morro está que arde. / El aire incómodo, grueso, / hace del menor movimiento un esfuerzo, / como andar bajo otra atmósfera, / entre paños húmedos, mudos, / en un caldo sucio de claras batidas. / Los carros, en el viaducto, / enganchan su ciempiés: / ojos encendidos, sudor de diesel, / ruido motor, angustia sorda. / El sol debía estar poniéndose, ahora / -- jpero cómo confirmar su trayectoria / debajo de esa cúpula de polvo, / este cielo invertido? / Mirar el mar no trae nịngún consuelo / (si es un perro inmenso, trémulo, / vomitando una espuma de bilis, / y viene a acabar de morir en nuestra puerta). / Una pelusa antagonista / cayó en las hojas de los crisantemos / y va oscureciendo, día a día, / los ojos de las margaritas, / el corazón de las rosas. / De madrugada, / muda en la caja refrigerada, / la carga de agujas cae quemando / tímpano, párpados: / El niño jugaba en la veranda. / Dicen que no lo percibió / ¿De qué otro modo podría todavía / haber volteado el rostro: “¡Papá! / ¡Creo que un bicho me picó!" tan pronto / la bala penetró en su cabeza?]

17 Marcelo Sandmann hace una excelente lectura del poema en "Poesia em estado de sítio", en Sebastião, 2002$02, \mathrm{pp}$. 82-87. Sugiere una lectura en que la bala ya salió disparada desde el comienzo del poema y sólo aparece al final, que es paralela a la que ofrezco del recuerdo imborrable que puede hasta causar insomnio.

18 Iumna Maria Simón, "Situação de sítio", pp. 151-152.

${ }^{19}$ Idem.

${ }^{20}$ Ibid., p. 153.

${ }^{21}$ Los libros son Collapsus linguae (1991), As banhistas (1993) y Sob a noite física (1996) y Versos de circunstância (2001). Posteriormente incorporó un nuevo título, Monodrama (2009), en el que me parece notable la presencia del poema "Limpeza do aparelho" porque contiene la pregunta "Mas não seria uma contradição (para não dizer uma obscenidade) querer transformar aquele poema em procedimento?", que se refiere al poema "Garota com xilofone na Telegraph Av." del mismo libro. El cuestionamiento aparece en los moldes de la metapoesía, de la poesía sobre la poesía, pero dando un "paso lateral" al terreno de la "ética de la composición", en que la palabra "obscenidade" es clave. La "limpieza del aparato" implica poner en duda la reducción de un poema a su mecanismo y vencer la tentación de convertirlo en fórmula. Carlito proyecta esta interrogante sobre su propio quehacẹr poético e incluso llega a referirse a un poema suyo anterior, "O monograma turqui", como parte de su reflexión. La tematización poetica de este cuestionamiento me parece un elemento más que se puede 
integrar al esquema de crisis dibujado por Iumna. Creo que se repite en el "Poema negativo", que abre el libro Estado crítico (2013) de Régịs Bonvicino, aunque de un modo no autorreflexivo, pues no se vuelca sobre la propia producción del autor, sino que arremete, en un tono de denuncia, contra los simuladores, los impostores, etc., con el mismo tono de autoridad que despliega -como bien señaló Weintraub- en Página orfã.

22 Flora Sussekind, "Desterritorialização e forma literária. Literatura brasileira contemporânea e experiência urbana", p. 67. Iumna menciona este artículo apuntando que "Apesar da abrangência sociológica desse estudo, com muitos dados paralelísticos, sou de opinião que o seu exemplário de espaços não-representacionais e operações de desterritorialização refere-se à violência em geral, sem considerar a particularidade histórica do fenômeno que se alastrou a partir dos meados da década de 1980". La observación es ambigua pues no se sabe qué se entiende por "violencia en general", cuál es la "particularidad histórica del fenómeno" que se solicita, pues podría tratarse desde una delimitación temporal más precisa (de ahí la mención de "mediados de la decada de 1980") o de una más clara articulación entre el texto y la situación social o más cercana a la que Iumna ofrece. Efectivamente, Sussekind da ejemplos, tanto de prosa como de poesía. Los de poesía se centran en los siguientes autores: Sebastião Uchoa Leite, Angela Melim, Italo Moriconi y Duda Machado. Me parece que la diferencia estriba en que Sussekind enfatiza el tema de la "desterritorialización", que toma de Deleuze y Guattari, mientras que Iumna se centra en las ideas de "retradicionalización" y "retorno de lo real", apoyada esta última en Hal Foster. Así se entiende que, a pesar de que el tema en el título del ensayo de Sussekind sea lo urbano, el análisis del caso de Angela Melim gire en torno a la imagen del horizonte como coyuntura redimensionadora de la relación entre el sujeto y el paisaje, siendo este horizonte muchas veces no de naturaleza urbana.

${ }^{23}$ Cf. Fabio Weintraub, “O tiro, o freio, o mendigo e o outdoor: representações do espaço urbano na poesia brasileira pós-1990", Universidade de São Paulo, Departamento de Teoria Literária e Literatura Comparada, São Paulo, 2013, pp. 105-106, 140-148.

24 [Barrabás // Ustedes no pueden velar / el cuerpo de mi marido / al lado de ese tipo / que la policía baleó // Perdón, discúlpenme / me imagino el dolor / de perder un hijo así joven // Mi Cícero / murió trabajando / Un tiro por la espalda / a las dos de la mañana / Al lado de ese tipo / su cuerpo no se va a congelar / Ni me insista / al lado de un criminal / mi marido no va a estar]

25 [Indisciplina // Saco vino, opaco / pantalón beige de brim deslavado / sandalias aún / no totalmente gastadas // con la mano en la quijada / sentado, con una mirada de Nacho / sin reloj en un marasmo / por las noches, usa una capucha negra // blusa roja, falda / azul estampada, dormitando / al sol del final de la tarde de / verano en una pose Emina // caída bermuda manchada / mirando la vista del viaducto / camiseta verde regata / pantalón beige, como un anónimo // en medio del tumulto de los carros y autobuses / de falda ancha, blusa escotada / fumando a la Eloise / ostensivamente // camiseta bordeaux, pantalón negro de nylon / con hilo blanco en las laterales / zapatos beige, como un Noah / cruzando la pasarela de la avenida // vacía, de pecho abierto / camiseta camuflada / pantalón blanco, cinturón Rucci, clásico / exhibiéndose // estilo Nu.Luxe / en la banca detrás de la estatua / blusa negra / estratégicamente rasgada // [...] // como una Inguna / andrajosa, en un / estilo apátrida / sentada en el murete del parque // cabeza baja / pegada a las rodillas, / corbata invisible Hugo Boss / camisa blanca, pantalón negro [...] la otra, a la Marika, vestido / rojo, descalza, en el calor / cara fea es hambre, seguro / camisa azul borracho // [...] // japonisme, tipo trapista / un Buda apestoso / cierre la bolsa / acabemos de una vez // silueta resçatada / blusa Fendi, pantalón Armani / zapatos Helmut Lang / la víctima lo reconoció en la calle // y llamó a la policía / jeans grises, tẹnis amarillos / desfilando / en la banqueta, lépido // [...] // botas agujeradas, grafito / à la Yves Saint Laurent / bajo el sol de cada día / muy glitz, muy glam]'

${ }^{26}$ Fabio Weintraub, “Caos moralizado". In: Jornal de Crítica, São Paulo, n. 12, junio 2007, p. 7.

27 João Adolfo Hansen, en el elogioso posfacio "A palavra-carcaça de Bonvicino" incluido en el libro, interpreta el poema "Prosa" de manera semejante: "a poesia é uma espéćie de miséria incluída na miséria maior que a desdenha e ignora" (p. 113).

${ }^{28}$ Flora Sussekind, op. cit., pp. 71-74. Como bien lo señala la autora, Sebastião Uchoa Leite analiza el tema en su ensayo "A metáfora da perseguição", incluido en el volumen Jogos e enganos (Editora 34-Editora UFRJ, Río de Janeiro, 1995, pp. 111-142). Además, Sussekind proporciona abundantes ejemplos del intercambio de papeles entre la figura del perseguidor y la del perseguido, pudiendo a veces estar la propia poesía jugando uno de ellos. Otra dinámica interesante se encuentra en el poema "Exibicionistas e voyeurs", del libro A ficçâo vida (1993).

${ }^{29}$ [Una incierta noche // Calculo las calles que atravieso / Viendo la copa de los árboles / Guiado por los follajes / Profusamente inmerso / En el vértigo inverso / De la hemorragia verde / Del ciclópico ojo / vegetal / Que me contempla]

${ }^{30}$ El sobreviviente // Otras veces uno pasa / Por la Azeredo Coutinho / Y ahí ve / Otro espécimen / De la / "humanidad en cuclillas" / (Marcel Mauss) / Una loca / Discute consigo misma / Hamlet a gritos / "Oh mi alma profética!") / Rápido rodeo / Ese "ser ahí" / En alto regocijo / De mi perfecto juicio".

31 Cf. Iumna Maria Simon y Vinicius Dantas, "Consistência de Corola" en Novos Estudos, no. 85, novembro 2009. Para los autores, tras la forma hay una interpretación: "a ansiedade referencial em Corola dramatiza, sob o signo de insatisfação e dor, a angústia psicológica e física da perda das relações com o mundo, em lugar de simplesmente se regozijar com o fato de que o aparelho da representação está abalado" (p. 230). Me parece más prudente mantener una posición neutra acerca de las causas.

$32 \mathrm{Cf}$. Hal Foster, El retorno de lo real: la vanguardia a finales de siglo. trad. Alfredo Brotons Muñoz, p. 129.

${ }^{33}$ Fabio Weintraub, "O tiro, o freio, o mendigo e o outdoor...”, pp. 27-28.

${ }^{34}$ Cf. Hal Foster, op. cit., pp. 136 y156.

35 Cf. Ibid., n. 49, p. 157. La idea de "defensa apotropaica" se utiliza aquí en el sentido de gesto que tiene el poder mágico de alejar el mal. En este caso, lo real amenazante.

${ }^{36}$ Hal Foster, op. cit., p. 136.

37 Idem.

${ }^{38}$ Hal Foster, op. cit., p. 140. 
${ }^{39}$ Hal Foster, op. cit., p. 143.

${ }^{40}$ Cf. Hal Foster, op. cit., pp. 141 y 144.

${ }^{41}$ Karl Erik Schøllhammer, "Realismo afetivo: evocar realismo além da representação", p. 132.

42 Weintraub, en su artículo "Caos moralizado", reconoce que estas pausas --ejemplificadas con los poemas "Rascunhọ" y "Cambio, exchange"-- podrían no tener un carácter epifânico. Anota que Hansen, en el posfacio del libro, sugiere que los elementos naturales surgen como blanco de la "predación hiperbólica", y que Alcir Pécora apoya esta interpretación apuntando que el "locus amoenus" se transforma en "locus terrificus", lo cual hace inviable cualquier epifanía. No obstante, los tres críticos coinciden en que es una manifestación de un yo lírico que se postula como crítico de la situación que transmite.

${ }^{43}$ Cf. Hal Foster, op. cit., p. 133.

44 Véase la nota 31.

${ }^{45}$ Iumna Maria Simon, op. cit., p. 153.

46 [Primera elegía // Sólo en la vejez conocí el brío / de vivir lentamente. / El rostro ya no tiene residencia, se mueve a cada / sorbo de sombras. // Hay más tierra bajo la piel que la tierra donde piso. / Atravesé el siglo y aún no me recorrí. // ¿Cuál es la seña que transporto? / ¿Soy un contrabando de Dios, que va callado dẹtro, , receloso de pronunciarse? // Condiciono los amores a una expectativa. / Pero es justamente ella la que me impide ser real. // Me he vuelto el diario de un viaje cancelado. / [...] ]

${ }^{47}$ La portada tiene una viñeta de un hombre encorvado con bastón sentado en una silla y luce la foto de los dedos entrelazados de unas manos. Varias ilustraciones se incluyen al inicio de cada elegía: un farol decimonónico, un bastón, una pipa, una pluma fuente, un paraguas, una silla, una maleta, unos anteojos, unas fichas de dominó y un reloj de bolsillo con tapa, todas alusivas a la vejez. Son un poco caricaturescas, pero cumplen la función de dar una idea del contenido.

48 La traducción de los fragmentos es la siguiente: [Mi actualidad es tener hambre, no evolucionamos ante el alimento]. [Nivelamos la cura al veneno, el tiempo discrimina su naturaleza. / Lo que llega atrasado o adelantado envenena. / O que es puntual cura]. [No sé absorber el mensaje del cambio de guardia / entre la lechuza y el zorzal. Mucho menos traducir / lo que siente el perro cuando percibe que el ave lacerada / no tenía huesos que compensaran el esfuerzo]. [Será la fidelidad una forma de traicionar?]. [No me empujen más, no voy por donde no sé. / Déjame pensar o cuerpo, deja que el cuerpo me piense].

${ }^{49}$ La traducción de los fragmentos es la siguiente: [Aquí nada es real. Pero ¿qué es real? / ¿La literatura o lo que escapa de la escritura? // La vida relatada, al no ser mía, es más mía siendo de otro].

${ }^{50}$ La página personal de Fabricio Carpinejar (http://www.carpinejar.com.br/) recoge su producción literaria y da cuenta de los premios que ha recibido, entre los que se encuentra el Prêmio Jabut 2009 de la Câmara Brasileira do Livro, en la categoría "Contos e Crônicas", por Canalha! La televisora Rede Gazeta tiene el siguiente sitio con noticias del programa $A$ Máquina: http://www.tvgazeta.com.br/amaquina/ El argumento operativo del programa es que la Máquina tiene preso al entrevistador y semanalmente recibe un invitado que es "capturado" por ella.

${ }^{51}$ Manuel da Costa Pinto, Antologia comentada da poesia brasileira do século 21, pp. 120-121.

52 Un ejemplo de estos enfoques es: Tarso de Melo, "Antecipações do jovem poeta" de la columna "Lesa-palavra" en ABC no. 8, Alpharrabio Editora, s/d, (http://www.alpharrabio.com.br/abc7.htm\#d)

53 Para Luiz Antonio de Assis Brasil, en Terceira sede, Carpinejar es capaz de cambiar una bella imagen por una "peligrosa sentencia sencilla", sea declarativa o interrogativa, y afirma que es peligrosa porque es más accesible a los novatọs, que toman la sencillez como algo que cualquiera puede lograr "Poeta da distância e da concisão, compromissado com o que há de vir", sin datos de publicación, consultado en

http://www.carpinejar.com.br/critica15.htm). El poeta Ricardo Corona encuentra en el libro refinamiento de lenguaje, osadía formal y vocabulario rebuscado, que remiten al universo clásico, y señala la creación de una voz poetica que "contamina" este universo con procedimientos contemporáneos. También observa que el libro puede ser leído como un solo poema de concisión moderna o como un "mar de haikús" "Sem o cheiro de naftalina" en Gazeta do Povo, "Caderno G", Curitiba, 21/01/2002 consultado en http://www.carpinejar.com.br/critica47.htm). 